OPEN ACCESS

Edited by: Santiago Gutierrez,

Universidad de León, Spain

Reviewed by:

Bruno Brito Lisboa, Secretaria Estadual da Agricultura,

Pecuária e Irrigação, Brazil Vasvi Chaudhry,

Eberhard Karls University of Tübingen,

Germany

*Correspondence:

Olimpia Pepe

olipepe@unina.it

${ }^{\dagger}$ These authors have contributed equally to this work and share first

authorship

Specialty section: This article was submitted to Microbial Symbioses,

a section of the journal

Frontiers in Microbiology

Received: 29 April 2020 Accepted: 03 August 2020

Published: 18 August 2020

Citation

Romano I, Ventorino $\mathrm{V}$ Ambrosino P, Testa A, Chouyia FE and Pepe O (2020) Development

and Application of Low-Cost and Eco-Sustainable Bio-Stimulant

Containing a New Plant Growth-Promoting Strain Kosakonia

pseudosacchari TL13.

Front. Microbiol. 11:2044.

doi: 10.3389/fmicb.2020.02044

\section{Development and Application of Low-Cost and Eco-Sustainable Bio-Stimulant Containing a New Plant Growth-Promoting Strain Kosakonia pseudosacchari TL13}

\author{
Ida Romano ${ }^{1+}$, Valeria Ventorino ${ }^{1 \dagger}$, Patrizia Ambrosino ${ }^{2}$, Antonino Testa ${ }^{1}$, \\ Fatima Ezzahra Chouyia ${ }^{1,3}$ and Olimpia Pepe ${ }^{1 *}$
}

\begin{abstract}
Department of Agricultural Sciences, University of Naples Federico II, Naples, Italy, ${ }^{2}$ Agriges S.r.l. - Nutrizione Speciale per L'Agricoltura Biologica e Integrata, San Salvatore Telesino, Italy, ${ }^{3}$ Department of Biology, Faculty of Sciences

and Techniques, Hassan II University of Casablanca, Casablanca, Morocco
\end{abstract}

The use of beneficial microbes as inoculants able to improve fitness, growth and health of plants also in stress conditions is an attractive low-cost and eco-friendly alternative strategy to harmful chemical inputs. Thirteen potential plant growth-promoting bacteria were isolated from the rhizosphere of wheat plants cultivated under drought stress and nitrogen deficiency. Among these, the two isolates TL8 and TL13 showed multiple plant growth promotion activities as production of indole-3-acetic acid (IAA), siderophores, ammonia, and 1-aminocyclopropane-1-carboxylic acid (ACC) deaminase production, the ability to solubilize phosphate as well as exerted antimicrobial activity against plant pathogens as Botrytis spp. and Phytophthora spp. The two selected strains were identified as Kosakonia pseudosacchari by sequencing of $16 \mathrm{~S}$ rRNA gene. They resulted also tolerant to abiotic stress and were able to efficiently colonize plant roots as observed in vitro assay under fluorescence microscope. Based on the best PGP properties, the strain K. pseudosacchari TL13 was selected to develop a new microbial based formulate. A sustainable and environmentally friendly process for inoculant production was developed using agro-industrial by-products for microbial growth. Moreover, the application of $K$. pseudosacchari TL13- based formulates in pot experiment improved growth performance of maize plants.

Keywords: inoculant, PGPR, rhizocompetence, bio-formulate, organic by-products

\section{INTRODUCTION}

According to the Food and Agriculture Organization (FAO), the estimated world population for 2025 will be nearly $8.5 \times 10^{9}$ inhabitants (Timmusk et al., 2017). Such an increase in agricultural production of $60 \%$ within the next years could be required to satisfy global food demand (Berger et al., 2018). Actually, in order to maintain a high quality of agricultural productions and eliminate or minimize yield loss, chemicals (fertilizers, pesticides, herbicides, etc.), hormones and antibiotics 
are commonly used for crops. The use of agrochemicals at industrial level allows to produce a large number of agricultural products at low costs with high profits for farmers. However, serious concerns regarding human and environmental health resulting from chemical residues in soil, water and food as well as farm workers' exposure have posed great attention (Alori and Babalola, 2018). Indeed, in the last two decades, the demand for organically grown agricultural products increased as consequence to the request for healthy and safe products (Dorais and Alsanius, 2016). Therefore, new eco-compatible strategies to improve agricultural systems and crop production are needed. The use of plant beneficial microorganisms as inoculants offers an attractive eco-friendly alternative strategy to chemical inputs to ensure crop yield and nutritional quality (Fiorentino et al., 2018) acting as agricultural probiotics. Probiotics are live microorganisms that offer benefits to the host providing nutritional inputs and protecting it from pathogens (Hossain et al., 2017). Among the beneficial microbes employed in agriculture, plant growth-promoting rhizobacteria (PGPR) are the most commonly used. These microbes are able by a wide range of mechanisms to improve nutrient availability in soil, plant nutrient uptake and assimilation [i.e., nitrogen fixation, phosphate solubilization, siderophore, indole3 -acetic acid (IAA), and ammonia production] and/or providing protection against plant pathogens (Backer et al., 2018; Woo and Pepe, 2018). Indeed, these microbes could also act as biostimulants ameliorating plant growth and crop production in response to abiotic stress in hostile environments (Viscardi et al., 2016; Van Oosten et al., 2017).

Important examples of PGPR include Pseudomonas, Bacillus, Azotobacter, Azospirillum, Burkholderia, Sphingomonas (Sharma et al., 2011; Singh et al., 2013; Castanheira et al., 2017; Dal Cortivo et al., 2017; Kandel et al., 2017; Khalid et al., 2017). However, in the last few years, it is rising the interest around the genus Kosakonia for its potential PGP activities. Recently, several members of this genus have been recognized as endophyte of different agricultural plants and it was demonstrated their growth-promoting effects and crop yield improvement (Kämpfer et al., 2016; Berger et al., 2017). However, this genus being relatively young, it is poorly studied and many of its features remain still unexplored.

Actually, the establishment of a low-cost and eco-sustainable process, as well as an effective and stable formulation, are among the main biotechnological challenges for the development of microbial inoculants. The use of agro-industrial organic waste and by-products as carbon source for the growth and production of microbial biomass is an attractive strategy to reduce the production costs, to valorize organic waste and by-products and to develop a sustainable and environmentally friendly process for inoculant production at industrial level. Moreover, it is also very important the form (solid or liquid) of microbial inoculant as well as its shelf-life. In fact, the form of the inoculant could influence its cost production, affect its efficiency and determine the method of application in agriculture on large scale (Alori and Babalola, 2018). The inoculant must be easy to handle in the field but it should maintain its features during the process and an adequate viability and shelf-life since it is required that it should be stable for at least 6 months (Berger et al., 2018).

This work aimed to isolate, select and characterize rhizobacteria with multiple PGP properties and antimicrobial activity. The selected plant growth-promoting bacteria (PGPB) strains were also tested for their ability to tolerate abiotic stress and to be able to efficiently colonize plant roots in in vitro experiments. Additionally, the selected strain was used to develop a new inoculant using agro-industrial by-products as sole carbon source for microbial growth and the new low-cost and eco-sustainable bio-formulates were finally tested in two forms (solid or liquid) in pot experiment to improve growth performance of maize plant.

\section{MATERIALS AND METHODS}

\section{Soil Sampling and Microbial Isolation}

Rhizosphere samples were collected according to Romano et al. (2020) from wheat plants grown, under drought stress and nitrogen deficiency, in a greenhouse at the experimental station of the University of Naples Federico II (Bellizzi, Italy; $43^{\circ} 31^{\prime} \mathrm{N}$, $14^{\circ} 58^{\prime} \mathrm{E}, 60 \mathrm{~m}$ a.s.l.). Ten grams of samples were shaken for $30 \mathrm{~min}$ in $90 \mathrm{~mL}$ of quarter strength Ringer's solution (Oxoid, Milan, Italy) containing tetrasodium pyrophosphate (16\% w/v) as previously described (Ventorino et al., 2012a). After shaking, tenfold serial dilutions (1:10) were performed and used to inoculate liquid Augier medium (Pepe et al., 2013) for the detection of free-living $\left(\mathrm{N}_{2}\right)$-fixing aerobic bacteria. After incubation for 14 days at $28^{\circ} \mathrm{C}$, the brown rings formed by microorganisms grew in the liquid medium were used to inoculate LG agar medium (Aquilanti et al., 2004). The plates were incubated for 7 days at $28^{\circ} \mathrm{C}$. Isolated colonies were picked from plates, purified by streaking on the same isolation medium, characterized by different morphologies examined by microscopy, gram staining and catalase reaction and stored at $4^{\circ} \mathrm{C}$ as slant cultures until their characterization.

\section{Preliminary Screening for Plant Growth Promoting Traits}

Thirteen bacterial isolates were screened on the basis of their potential plant growth promotion activities. Detection and quantification of IAA production was determined by the Salkowski colorimetric assay using Nutrient Broth (Oxoid) with and without 1-tryptophan (2 $\mathrm{mg} \mathrm{L}^{-1}$; Sigma-Aldrich, Milan, Italy) as previously described (Ventorino et al., 2014).

Semi-quantitative agar spot method was used to determine the ability of bacterial isolates to produce siderophores by Chrome azurol S (CAS) assay as described by Silva-Stenico et al. (2005). After 14-21 days of incubation at $28^{\circ} \mathrm{C}$, the formation of an orange or yellow halo around the colony indicated the production of siderophores by the microorganism.

Determination of 1-aminocyclopropane-1-carboxylic acid (ACC) deaminase activity of isolates was performed by assessing the growth on nitrogen-free minimal medium (MM) agar supplemented with $3 \mathrm{mM}$ ACC (Sigma-Aldrich) after incubation at $28^{\circ} \mathrm{C}$ in the dark for 7 days as described by 
Jaemsaeng et al. (2018). MM agar supplemented with $2 \mathrm{~g} \mathrm{~L}^{-1}$ $\left(\mathrm{NH}_{4}\right)_{2} \mathrm{SO}_{4}$ was used as control.

\section{Identification of Selected Strains}

The bacterial isolates showing the highest plant growth promoting activities were selected for further investigations and identified by the sequencing of the $16 \mathrm{~S}$ rRNA gene. In detail, total genomic DNA of selected strains was extracted by boiling for $10 \mathrm{~min}$ and then used as template for the PCR assay. The PCR mixture was employed according to Alfonzo et al. (2012) using the primers fD1 (5'-AGAGTTTGATCCTGGCTCAG-3') and rD1 (5'-AAGGAGGTGATCCAGCC- $\left.3^{\prime}\right)$. The PCR conditions were as described by Ventorino et al. (2017). PCR products were purified using the QIAquick PCR Purification Kit (Quiagen, Milan, Italy) according to the supplier's recommendations and sequenced as previously reported (Ventorino et al., 2016). The DNA sequences were compared to the GenBank nucleotide data library using the BLAST software at the National Centre for Biotechnology Information website ${ }^{1}$.

The nearly full-length $16 \mathrm{~S}$ rRNA sequences of the selected bacterial strain and 31 type strains belonging to different genera related to Kosakonia pseudosacchari species as described by Kämpfer et al. (2016) and Wang et al. (2019) were used to perform multiple nucleotide alignments using the ClustalW program (Thompson et al., 1994) from MEGA version X (Kumar et al., 2018; Stecher et al., 2020). The nucleotide sequences of the type strains were retrieved from the Ribosomal Database Project (RDP) ${ }^{2}$ and from the National Center for Biotechnology Information $(\mathrm{NCBI})^{3}$. The phylogenetic tree was inferred using the Neighbor-Joining method with the Maximum Composite Likelihood model in the MEGAX program, with bootstrap values based on 1,000 replications.

The 16S rRNA gene sequences obtained from selected bacterial strains were deposited in the GenBank nucleotide database under accession numbers MN607213 and MN607214 (see footnote 3 ).

\section{Characterization of Selected Strains for PGP Traits and Antimicrobial Activity}

Phosphate solubilization ability was quantified by molybdenum blue quantitative assay in Pikovskaya's (PVK) liquid medium. Briefly, $10 \mathrm{~mL}$ of PVK medium was inoculated with $0.1 \mathrm{~mL}$

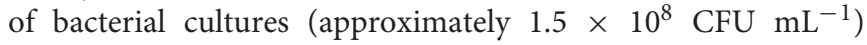
and incubated for 15 days at $30^{\circ} \mathrm{C}$. After incubation, cultures were centrifuged $(5 \mathrm{~min}$ at $18,620 \times g)$ and supernatant was collected to estimate released soluble phosphorus (P) as described by Murphy and Riley (1962). The concentration of $\mathrm{P}$ solubilized was determined by spectroscopic absorbance measurements at $430 \mathrm{~m} \mu$ according to the standard curve (Murphy and Riley, 1962).

Ammonia production of selected strains was estimated by inoculating the microorganisms in $5 \mathrm{~mL}$ of peptone water according to Cappuccino and Sherman (1987) and incubating

\footnotetext{
${ }^{1}$ http://www.ncbi.nlm.nih.gov/Blast.cgi

${ }^{2}$ https://rdp.cme.msu.edu/

${ }^{3}$ https://www.ncbi.nlm.nih.gov
}

under shaking $(100 \mathrm{rpm})$ at $30^{\circ} \mathrm{C}$ for 7 days. The presence of ammonia was detected by the development of a brown to yellow color after adding $0.5 \mathrm{~mL}$ of Nessler's reagent (SigmaAldrich) to the culture and then quantified by spectroscopic absorbance measurements at $420 \mathrm{~nm}$ according to the standard curve (Passari et al., 2017).

The presence of the target gene nif $\mathrm{H}$, encoding nitrogenase reductase enzyme, was assessed by PCR assay using the synthetic oligonucleotide primers nif $\mathrm{H}$-F (5'-AAAGGYGGWAT CGGYAARTCCACCAC-3' ${ }^{\prime}$; Rösch et al., 2002) and nif H-R, (5' TTGTTSGCSGCRTACATSGCCATCAT-3'; Rösch et al., 2002) using conditions reported by Fiorentino et al. (2016). The presence of the target gene was assessed by visualization of a 475 bp band by agarose $(1.5 \% \mathrm{w} / \mathrm{v})$ gel electrophoresis (100 V for about $1 \mathrm{~h}$ ).

A 1-aminocyclopropane-1-carboxylic acid deaminase activity was quantified according to Penrose and Glick (2003) by measuring the amount of $\alpha$-ketobutyrate (Sigma-Aldrich) produced when the enzyme ACC deaminase cleaves ACC. In detail, bacterial strains were inoculated in $5 \mathrm{~mL}$ of Dworkin and Foster (DF) minimal salt medium containing $\left(\mathrm{NH}_{4}\right)_{2} \mathrm{SO}_{4}$ as sole nitrogen source (Penrose and Glick, 2003). After incubation at $30^{\circ} \mathrm{C}$ for $48 \mathrm{~h}$, the cultures were used to inoculate $5 \mathrm{~mL}$ of DF salt medium containing $3 \mathrm{mM}$ ACC (Oxoid) as nitrogen source. The amount of $\alpha$-ketobutyrate $(\mu \mathrm{mol}$ ) produced was estimated by measuring the absorbance at $540 \mathrm{~nm}$ according to the standard curve ( $\alpha$-ketobutyrate concentration ranged from 0.1 to $100 \mu \mathrm{mol})$.

Quantitative estimation of siderophores was performed according to Arora and Verma (2017) using CAS reagent and expresses as percent siderophore unit (psu) using the following formula (Payne, 1993):

$$
\mathrm{psu}=[(\mathrm{Ar}-\mathrm{As}) \times 100] / \mathrm{Ar}
$$

where $\mathrm{Ar}$ is the absorbance of reference (CAS solution and uninoculated medium), and As is the absorbance of sample (CAS solution and cell-free sample supernatant).

Antimicrobial antagonism was evaluated using the dual culture method described by Hammami et al. (2013) against eight pathogenic eukaryotic strains belonging to the microbial collection of Division of Biology and Protection of Agricultural and Forest Systems (Department of Agricultural Sciences, University of Naples Federico II): Botrytis cinerea B11, B. cinerea B12, Fusarium oxysporum F3, F. oxysporum F5, Aspergillus niger A31, Phytophthora infestans ph1, Phytophthora cactorum ph3, and Phytophthora cryptogea ph4. Fungi were grown on Potato Dextrose Agar (PDA, Oxoid) at $28^{\circ} \mathrm{C}$ for 7 days, while Oomycetes were grown on V8 agar $(200 \mathrm{~mL}$ of V8 juice, $2.5 \mathrm{~g}$ $\mathrm{CaCO}_{3}, 800 \mathrm{~mL}$ of distilled water and $17 \mathrm{~g}$ of bacteriological agar) at $28^{\circ} \mathrm{C}$ for 21 days. Conidia were harvested from the surface of plates by flooding the cultures with $9 \mathrm{~mL}$ of sterilized distilled water and gently scraping with a sterilized glass rod. The conidial concentration was determined using the counting chamber Thoma (Hawksley, United Kingdom). An over-layer agar (agar $0.7 \%$ ) containing a concentration of $10^{5}$ conidia $\mathrm{mL}^{-1}$ of each plant pathogen was poured on Brain Heart Infusion (BHI) 
agar plates previously spotted with the bacterial strains. After incubation for 7 or 21 days at $28^{\circ} \mathrm{C}$, the antimicrobial activity of the bacterial strains was highlighted by the presence of a halo around the colony without fungal growth.

\section{Tolerance to Abiotic Stress}

The two selected bacterial strains were tested for their salt tolerance in liquid medium as previously described Ventorino et al. (2012b). Briefly, $5 \mathrm{~mL}$ of BHI medium supplemented with $\mathrm{NaCl}$ up to $15 \%(\mathrm{w} / \mathrm{v})$ was inoculated with each bacterial strain. The standard BHI medium with $0.5 \%$ (w/v) $\mathrm{NaCl}$ was used as control. Bacterial growth was determined by observing the development of turbidity of cultures at 24 and $48 \mathrm{~h}$ and comparing them with McFarland Turbidity Standard.

Similarly, temperature tolerance was investigated comparing bacterial growth in BHI liquid medium with McFarland Turbidity Standard after 24 and $48 \mathrm{~h}$ of incubation at 28, 30, 37 , and $42^{\circ} \mathrm{C}$.

Finally, $\mathrm{pH}$ tolerance was determined by evaluating the growth of bacterial strains in BHI liquid medium in which $\mathrm{pH}$ was adjusted at $\mathrm{pH} 5,6,7$, and 8 by the addition of $\mathrm{HCl}$ or $\mathrm{NaOH}$. After incubation, bacterial growth was estimated at 24 and $48 \mathrm{~h}$ comparing their turbidity to McFarland Turbidity Standard.

\section{Rhizosphere Competence}

Tomato seeds (Solanum lycopersicum var. cerasiforme) were carefully de-husked without damaging the embryo and surface sterilized as described by Banik et al. (2016). Briefly, seeds were treated with $2 \%$ sodium hypochlorite $(5 \mathrm{~min})$ followed by washing with sterile distilled water, then seeds were treated with $75 \%$ ethanol ( $5 \mathrm{~min}$ ), washed again with sterile water and treated with $30 \%$ hydrogen peroxide $(2 \mathrm{~min}$ ) as suggested by Amarasinghe et al. (2018); finally, they were carefully rinsed ten times with sterile distilled water. Seeds sterility was checked by plating on Plate Count Agar (PCA; Oxoid). Seeds germination took place in darkness at $30 \pm 2{ }^{\circ} \mathrm{C}$.

Microbial cells were grown in $\mathrm{BHI}$ medium $\left(30 \pm 2^{\circ} \mathrm{C}\right.$, $24 \mathrm{~h})$. Cells were harvested by centrifugation $(2000 \times g$ for $5 \mathrm{~min}$ ) at the end of their exponential phase of growth, washed twice in HEPES buffer $(0.1 \mathrm{M})$ and then suspended in quarter strength Ringer's solution (Oxoid) until achieving microbial concentration of approximately $5 \times 10^{8} \mathrm{CFU} \mathrm{mL}^{-1}$ (counting chamber Thoma 0.02 depth, Hawksley United Kingdom). Finally, tomato seedlings were treated with bacterial suspension for $48 \mathrm{~h}$ at $30 \pm 2{ }^{\circ} \mathrm{C}$ and then rinsed five times with sterile HEPES buffer $(0.1 \mathrm{M})$ to remove the loosely associated bacteria from the radicle surface. Tomato seedlings treated with sterile water were used as control. Bacteria-infected radicles and controls were treated with LIVE/DEAD ${ }^{\circledR}$ BacLight $^{\text {TM }}$ bacterial viability kit (Thermo Fisher Scientific) following the manufacturer's instructions. Treated radicles were observed by fluorescence microscope (Axiovert 200M, Zeiss, Göttingen, Germany) under UV light (50-W mercury lamp) and using a Green Fluorescent Protein Filter (38 HE-GFP; excitation wavelength of 450-490 nm) and Rhodamine Filter (Rh-20; excitation wavelength of 540-552 nm).

\section{Production of a Low-Cost Bacterial Inoculants}

\section{Study of Bacterial Growth}

The strain TL13 was inoculated in $200 \mu \mathrm{L}$ of BHI using 96-well flat-bottom microplate in a Microplate Reader (BioTek Elx808) and incubated at $30^{\circ} \mathrm{C}$ for $24 \mathrm{~h}$ with moderate shaking every $30 \mathrm{~min}$. O. $\mathrm{D}_{600 \mathrm{~nm}}$ measurements were performed every $30 \mathrm{~min}$ to define the growth curve.

Preliminary batch growth tests were performed to assess the best growth conditions for the strain TL13. In details, $500 \mathrm{~mL}$ flasks filled with BHI medium were inoculated with $2 \%$ bacterial

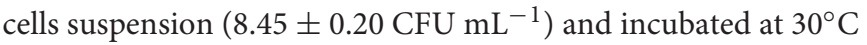
for $24 \mathrm{~h}$ using three different growth conditions: (1) Batch 1, shaking at $130 \mathrm{rpm}$ (Grant-bio, Orbital Shaker-Incubator ES80); (2) Batch 2, shaking at $130 \mathrm{rpm}$ and sterile air sparging at $0.5 \mathrm{vvm}$; control, no shaking and no air sparging. Samples were withdrawn every $2 \mathrm{~h}$ and cell growth was determined by viable counting on BHI medium.

A scale-up batch experiment was performed in a $14 \mathrm{~L}$ fermentor (New Brunswick BioFlo ${ }^{\circledR} /$ CelliGen ${ }^{\circledR}$ 115, Eppendorf) to evaluate the microbial growth using the best conditions assessed in the preliminary batch experiments. The experiment was performed in a working volume of $4 \mathrm{~L}$ of BHI medium inoculated with $2 \%$ bacterial cells suspension $(8.67 \pm 0.40 \mathrm{CFU}$ $\mathrm{mL}^{-1}$ ), using the following parameters: $30^{\circ} \mathrm{C}, \mathrm{pH} 7.00$, agitation of $130 \mathrm{rpm}$, air sparging at $0.5 \mathrm{vvm}, 40 \mathrm{~mL}$ of a solution 3\% of Antifoam 204 (Sigma-Aldrich) added at the beginning of the process. Samples were withdrawn every $2 \mathrm{~h}$ and cell growth was determined by viable counting on BHI medium. After $24 \mathrm{~h}$, the culture was centrifuged $(45 \mathrm{~min}$ at $3428 \times \mathrm{g}$ ) and recovered cells were suspended in a $5 \%$ sucrose solution at the ratio $1: 5(\mathrm{w}: \mathrm{v})$. The strain was freeze-dried, and cell viability was determined by counting on BHI medium immediately after freeze-drying and after 3 and 6 months of storage at room temperature.

\section{Microbial Growth in Liquid Media Containing Food By-Products}

The strain TL13 was inoculated in several liquid media containing agro-food industrial by-products to find a low-cost carbon source useful for its growth. To this end, the strain was inoculated into $10 \mathrm{~mL}$ of liquid substrates containing 1,5 or $10 \%$ of whey, protein hydrolysate, exhausted yeasts, molasse or vinasse, kindly provided by Agriges S.r.l. (San Salvatore Telesino, Benevento, Italy). The strain TL13 grown in BHI was used as control. Samples were withdrawn after $48 \mathrm{~h}$ of incubation at $30^{\circ} \mathrm{C}$, to determine bacterial growth.

\section{Production of Bacterial Inoculants on Nutrient-Supplemented Vermiculite}

Solid state fermentation (SSF) was performed in gas permeable polypropylene bags (SacO2, Belgium). Growth on inert support was carried out by adopting the procedures described by Graham-Weiss et al. (1987). Sterile vermiculite, moistened with BHI broth or with a solution of exhausted yeasts and vinasse, was inoculated with the selected strain TL13 $\left(10^{6}\right.$ bacterial cells per $g$ of vermiculite). After incubation (15 days at $30 \pm 1^{\circ} \mathrm{C}$ ), 
an aliquot was used to develop liquid inoculants recovering the bacterial cells and added them in a raw castor oil/alginate based emulsion following the protocol described by Fravel et al. (1985) with some modifications. Another amount of inoculated vermiculite was dried for 15 days at $30 \pm 2{ }^{\circ} \mathrm{C}$ to achieve a microbial-based solid formulation. Samples were withdrawn immediately after incubation and after the development of formulations to determine bacterial growth by viable counting on BHI medium.

\section{Pot Trials}

The ability of the selected strain TL13 to promote plant growth was evaluated in growth chamber pot trials. The experimental set up was performed according to standard procedure (DM 27/01/2014, 2014) with some modifications. Maize (Zea mays, Class FAO 400/gg 120) seeds were surface sterilized by $5 \mathrm{~min}$ washing in $\mathrm{NaClO} 5 \%$ solution and germinated on damp tissue paper for $48 \mathrm{~h}$. Seeds were planted in $10 \mathrm{~cm} \varnothing$ plastic pots filled with $0.5 \mathrm{~kg}$ of unsterilized soil (35\% clay, $27 \%$ silt and $38 \%$ sand; $\mathrm{pH}-\mathrm{H}_{2} \mathrm{O}$ 7.7; electrical conductivity $0.6 \mathrm{dS} \mathrm{m}{ }^{-1} ; \mathrm{CaCO}_{3} 37 \mathrm{~g}$ $\mathrm{kg}^{-1}$; organic matter $16.3 \mathrm{~g} \mathrm{~kg}^{-1}$; organic carbon $9.5 \mathrm{~g} \mathrm{~kg}^{-1}$; total nitrogen $1.2 \mathrm{~g} \mathrm{~kg}^{-1}$; $\mathrm{C} / \mathrm{N}$ ratio 7.9 ; phosphorus available $59 \mathrm{mg} \mathrm{kg}^{-1}$; potassium exchangeable $296 \mathrm{mg} \mathrm{kg}^{-1}$; calcium exchangeable $2089 \mathrm{mg} \mathrm{kg}^{-1}$; magnesium exchangeable $111 \mathrm{mg}$ $\mathrm{kg}^{-1}$; sodium exchangeable $57 \mathrm{mg} \mathrm{kg}{ }^{-1}$; Cation Exchange Capacity $\left.12.1 \mathrm{cmol}(+) \mathrm{kg}^{-1}\right)$. At planting, soil was inoculated with the strain TL13 at a concentration of approximately $1 \times 10^{6}$ cells $\mathrm{g}^{-1}$.

The strain TL13 was inoculated in three different formulates: raw castor oil/alginate based emulsion (E-TL13), dried vermiculite (V-TL13) and recovered cells (R-TL13) diluted in sterile Ringer's solution (Oxoid). Un-inoculated soil (C) was used as control. All tests were performed in triplicate and three seeds were planted for each pot.

Plants were grown under controlled conditions with a constant temperature of $28 \pm 0.5^{\circ} \mathrm{C}$, a $16 \mathrm{~h}$ light $/ 8 \mathrm{~h}$ dark photoperiod, relative moisture $70 \%$ and daily watered for 15 days.

After 15 days, the plants were sampled and were measured vegetative parameters as total plant length, root and shoot length, root and shoot fresh weight, root and shoot dry weight percentage.

\section{Statistical Analyses}

Data were analyzed by one-way ANOVA followed by Duncan's HSD post hoc for pairwise comparison of means (at $P<0.05$ ) using SPSS 19.0 statistical software package (SPSS Inc., Cary, NC, United States).

\section{RESULTS}

\section{Plant Growth Promoting Activities of Bacterial Isolates}

A total of 13 bacterial isolates (from TL1 to TL13) were obtained from the rhizosphere of wheat plants using Augier liquid medium followed by streaking on LG agar medium. Isolates were preliminarily screened for their potential plant growth promoting activities, as IAA and siderophores production and ACC-deaminase activity (Table 1).

The results indicated that about $85 \%$ of isolates were able to synthetize IAA, although most of them at low amounts (ranging from 1.32 to $5.98 \mathrm{mg} \mathrm{L}^{-1}$ ). The two isolates, TL8 and TL13, showed the highest IAA production up to $13.20 \pm 1.80$ or $22.16 \pm 2.67$ and $12.91 \pm 0.64$ or $33.26 \pm 1.67 \mathrm{mg}$ $\mathrm{L}^{-1}$, respectively, in the absence and in the presence of L-tryptophan (Table 1).

Ten isolates produced siderophores showing orange haloes around the colony in CAS agar ranging from 10 to $35 \mathrm{~mm}$ (Table 1). Among these, the isolates TL3, TL4, and TL13 exhibited the highest siderophores production (halo dimension 30-33 mm); while, the isolates TL1, TL3, TL7, TL8, and TL12 produced haloes ranging approximately from 20 to $23 \mathrm{~mm}$.

Moreover, seven isolates (TL1, TL2, TL4, TL6, TL7, TL8, and TL13), corresponding to about 54\%, revealed ACC-deaminase activity because they were able to grow on MM medium supplemented with ACC (Table 1).

\section{Identification and Phylogenetic Analysis of Selected Strains}

The preliminary screening for the assessment of plant growth promotion activities allowed for the selection of the TL8 and TL13 isolates. The nearly full-length sequence of $16 \mathrm{~S}$ rRNA gene (about $1,450 \mathrm{bp}$ ) of the strains TL8 and TL13 revealed an identity of $99 \%$ with Kosakonia sacchari, K. pseudosacchari, Kosakonia oryzae, and Kosakonia radicincitans species using Blast software. To establish the identification of the two selected strains, a phylogenetic tree generated from the distance data using the Neighbor-Joining method with the Maximum Composite

TABLE 1 | Preliminary screening for the assessing the plant growth-promoting activities of bacterial isolates obtained from wheat rhizosphere.

\begin{tabular}{|c|c|c|c|c|}
\hline Isolate & $\begin{array}{l}\mathrm{IAA}^{\dagger} \text { in } \mathrm{NB} \\
\left(\mathrm{mg} \mathrm{L}^{-1}\right)\end{array}$ & $\begin{array}{c}\text { IAA }^{\S} \text { in } \\
\mathrm{NB}+\mathrm{TRP}^{-} \\
\left(\mathrm{mg} \mathrm{L}^{-1}\right)\end{array}$ & $\begin{array}{l}\text { Siderophores }{ }^{\#} \\
(\mathbf{m m})\end{array}$ & $\begin{array}{c}\text { ACC- } \\
\text { deaminase } \\
\text { activity* }\end{array}$ \\
\hline TL1 & $2.59 \pm 0.06^{g-m}$ & $0.00 \pm 0.00^{n}$ & $20.0 \pm 0.00^{c d}$ & ++ \\
\hline TL2 & $3.16 \pm 0.50^{g-i}$ & $1.82 \pm 0.31^{i-m}$ & $0.00 \pm 0.00^{f}$ & + \\
\hline TL3 & $1.56 \pm 0.07^{1-n}$ & $1.32 \pm 0.02^{m n}$ & $30.0 \pm 0.00^{a b}$ & - \\
\hline TL4 & $3.40 \pm 0.02^{f-h}$ & $4.90 \pm 0.63^{d e}$ & $33.33 \pm 5.77^{a}$ & + \\
\hline TL5 & $1.62 \pm 0.02^{i-m}$ & $1.42 \pm 0.00^{m n}$ & $23.33 \pm 5.77^{b c}$ & - \\
\hline TL6 & $5.98 \pm 1.03^{d}$ & $3.95 \pm 0.33^{e-g}$ & $10.0 \pm 0.00^{e}$ & ++ \\
\hline TL7 & $5.89 \pm 0.60^{d}$ & $5.15 \pm 0.51^{d e}$ & $23.33 \pm 5.77^{b c}$ & ++ \\
\hline TL8 & $13.20 \pm 1.80^{c}$ & $12.91 \pm 0.64^{c}$ & $23.33 \pm 11.55^{b c}$ & ++ \\
\hline TL9 & $0.00 \pm 0.00^{n}$ & $0.00 \pm 0.00^{n}$ & $0.00 \pm 0.00^{f}$ & - \\
\hline TL10 & $1.68 \pm 0.67^{i-m}$ & $4.69 \pm 1.32^{d-f}$ & $0.00 \pm 0.00^{f}$ & - \\
\hline TL11 & $2.23 \pm 0.02^{h-m}$ & $0.00 \pm 0.00^{n}$ & $13.33 \pm 5.77^{e}$ & - \\
\hline TL12 & $1.43 \pm 0.02^{m n}$ & $3.05 \pm 0.07^{g-1}$ & $20.0 \pm 0.00^{c d}$ & - \\
\hline TL13 & $22.16 \pm 2.67^{b}$ & $33.26 \pm 1.67^{a}$ & $30.0 \pm 0.00^{a b}$ & ++ \\
\hline
\end{tabular}

${ }^{\dagger}$ IAA production in Nutrient Broth without L-tryptophan, values represent the means $\pm S D$ of three replicates. ${ }^{\$} / A A$ production in Nutrient Broth supplemented with L-tryptophan, values represent the means $\pm S D$ of three replicates. "Halo size $(\mathrm{mm})=$ diameter of clearing or halo zone/colony diameter, values represent the means $\pm S D$ of three replicates. Different letters after values indicate significant differences $(P<0.05)$. * no growth; + middle growth; ++ high growth. 


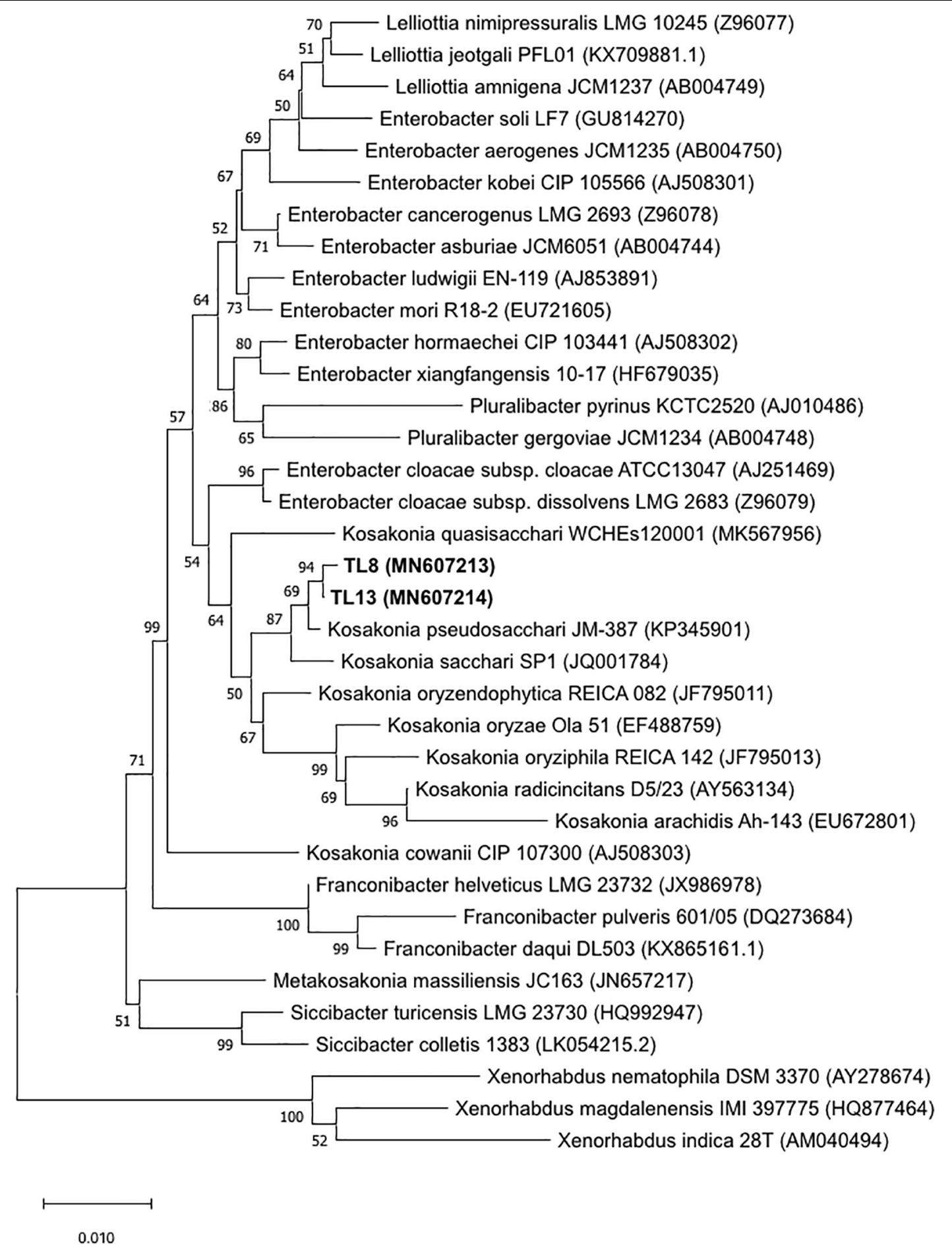

FIGURE 1 | Neighbor-Joining tree based on the comparison of 16S rRNA gene sequences of bacterial strains TL8 and TL13 and 31 type strains related to genus Kosakonia sequences from RDP and NCBI. Bootstrap values (expressed as percentages of 1,000 replications) are given at the nodes. The sequence accession numbers used for the phylogenetic analysis are shown in parentheses following the species name. Xenorhabdus type strain sequences were used as out group. The scale bar estimates the number of substitutions per site.

Likelihood model in the MEGAX Program was constructed including the $16 \mathrm{~S}$ rRNA sequences of type strains related to Kosakonia genus (Figure 1). High bootstrap values, ranging from
50 to $100 \%$, were observed and indicated significant branching points in the phylogenetic tree. The phylogenetic tree indicated that the closest relative species of the two selected strains 
was K. pseudosacchari (cluster with bootstrap value of $69 \%$ ), demonstrating that the strains TL8 and TL13 can be classified as belonging to this species (Figure 1).

\section{PGP Traits, Phenotypic Characteristics and Rhizosphere Competence of Kosakonia pseudosacchari Strains}

The selected strains K. pseudosacchari TL8 and TL13 were further characterized to evaluate other plant growth promotion activities as well as antagonistic behaviors. Quantitative estimation of phosphate solubilization by molybdenum blue assay in PKV liquid medium indicated that the strains TL8 and TL13 were able to solubilize up to $348.05 \pm 12.77$ and $346.05 \pm 25.62 \mathrm{mg} \mathrm{L}^{-1}$ of phosphate starting from dicalcium phosphate (Table 2). Measurement of ammonia in peptone water liquid medium by quantitative Nessler's reagent test highlighted that both bacterial strains TL8 and TL13 were capable to produce ammonia $(2.24 \pm 0.03$ and $2.37 \pm 0.03 \mathrm{mg}$ $\mathrm{L}^{-1}$, respectively; Table 2) in medium without nitrogen source. Moreover, K. pseudosacchari TL8 and K. pseudosacchari TL13 were potentially able to fix atmospheric nitrogen $\left(\mathrm{N}_{2}\right)$ due to the presence of the nif $\mathrm{H}$ gene detected by specific PCR amplification as well as exhibited ACC deaminase activity producing up to $3.04 \pm 0.10$ and $3.31 \pm 0.11 \mu \mathrm{M}$ of $\alpha$-ketobutyrate protein $\mathrm{mg}^{-1}$ in $30 \mathrm{~min}$ (Table 2 ). As reported in Table 2, quantitative assay showed a siderophore concentration produced by the strains $K$. pseudosacchari TL8 and TL13 equal to $32.00 \pm 0.92$ and $29.77 \pm 1.8 \mathrm{psu}$, respectively. Indeed, both strains exerted antimicrobial activity against soilborne plant pathogens (Table 2) revealed by a considerable reduction of mycelium growth of $B$. cinerea $\mathrm{B} 12, P$. infestans ph1, $P$. cactorum ph3, and $P$. cryptogea ph4, in respect to the control plates.

Kosakonia pseudosacchari TL8 and TL13 were found to be salt-tolerant because they were able to grow in the liquid culture medium containing up to $13 \% \mathrm{w} / \mathrm{v}$ of $\mathrm{NaCl}$ (Table 2). In detail, no differences were found in the bacterial growth up to $8.0 \%$ w/v of $\mathrm{NaCl}$ reaching a concentration of about $1 \times 10^{8} \mathrm{CFU}$ $\mathrm{mL}^{-1}$ after $24 \mathrm{~h}$ of incubation (Table 2). At higher $\mathrm{NaCl}$ concentration (from 9.0 to $13 \% \mathrm{w} / \mathrm{v}$ ) the two strains grew slowly reaching a bacterial growth of two orders of magnitude lower (about $1 \times 10^{6} \mathrm{CFU} \mathrm{mL} \mathrm{mL}^{-1}$ ) after $48 \mathrm{~h}$ of incubation (Table 2). The two strains K. pseudosacchari TL8 and TL13

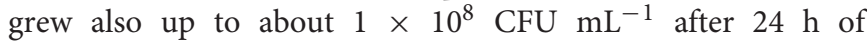
incubation at different temperatures $\left(28,30,37\right.$, and $\left.42^{\circ} \mathrm{C}\right)$. Finally, both strains tolerated a $\mathrm{pH}$ range between 4.0 and 8.0 reaching a final concentration of about $1 \times 10^{8} \mathrm{CFU} \mathrm{mL} \mathrm{m}^{-1}$ after 24 h (Table 2).

In order to test the ability of the two selected strains K. pseudosacchari strains TL8 and TL13 to colonize the root surface, sterile tomato radicles were inoculated and observed by fluorescence microscope after staining with the LIVE/DEAD ${ }^{\circledR}$ BacLight $^{\text {TM }}$ kit reagents. As shown in Figure 2, bacterial cells were clearly visualized on plant tissues highlighting that both $K$. pseudosacchari TL8 and K. pseudosacchari TL13 successfully colonized tomato's radicle. In particular, bacterial cells of the strains TL8 resulted congregated on root surfaces (Figure 2a); whereas, cells of the strain TL13 appeared scattered (Figure 2b).

\section{Investigation and Optimization of Growth Conditions}

On the basis of PGP traits, the strain K. pseudosacchari TL13 was selected for further investigations in order to produce an innovative bacterial inoculant.

The first step was to explore and define the best growth conditions of the strain K. pseudosacchari TL13. To this end, a kinetic growth curve of the strain TL13 was obtained by Microplate Reader test. This preliminary investigation showed that the exponential phase started after $4 \mathrm{~h}$ of incubation and continued until $10 \mathrm{~h}$, when begun the stationary phases (data not shown).

Batch experiments were then performed to investigate the effect of agitation and air sparging on the bacterial growth. The highest bacterial concentration in the shorter time was recorded in the batch 2 reaching a value of $8.87 \pm 0.02 \log$ $\mathrm{CFU} \mathrm{mL} \mathrm{m}^{-1}$ after $8 \mathrm{~h}$ of incubation (Figure 3 ), after that, a significant decrease in its concentration was observed. Similarly, in the batch 1 was detected an increase of three orders of magnitude at 10 and $12 \mathrm{~h}\left(8.88 \pm 0.00 \log \mathrm{CFU} \mathrm{mL} \mathrm{mL}^{-1}\right.$ and

TABLE 2 | Differential phenotypic characteristics and plant growth-promoting traits of bacterial strains Kosakonia pseudosacchari TL8 and TL13.

\begin{tabular}{|c|c|c|}
\hline $\begin{array}{l}\text { Characteristic/ } \\
\text { Activity }\end{array}$ & $\begin{array}{c}\text { Kosakonia } \\
\text { pseudosacchari TL8 }\end{array}$ & $\begin{array}{c}\text { Kosakonia } \\
\text { pseudosacchari TL13 }\end{array}$ \\
\hline IAA in $\mathrm{NB}^{\dagger}\left(\mathrm{mg} \mathrm{L}^{-1}\right)$ & $13.20 \pm 1.80$ & $22.16 \pm 2.67$ \\
\hline $\begin{array}{l}\text { IAA in } N B+T^{\S} \\
\left(m g L^{-1}\right)\end{array}$ & $12.91 \pm 0.64$ & $33.26 \pm 1.67$ \\
\hline $\begin{array}{l}\text { Siderophores } \\
\text { production (psu) }\end{array}$ & $32.00 \pm 0.92$ & $29.77 \pm 1.8$ \\
\hline $\begin{array}{l}\text { ACC-deaminase } \\
\text { activity ( } \mu \mathrm{M} \text { of } \\
\alpha \text {-ketobutyrate protein } \\
\mathrm{mg}^{-1} \text { in } 30 \text { min) }\end{array}$ & $3.04 \pm 0.10$ & $3.31 \pm 0.11$ \\
\hline $\begin{array}{l}\mathrm{Ca}_{2} \mathrm{HPO}_{4} \text { solubilization } \\
\left(\mathrm{mg} \mathrm{L}^{-1}\right)\end{array}$ & $348.05 \pm 12.77$ & $346.05 \pm 25.62$ \\
\hline $\mathrm{NifH}$ gene & + & + \\
\hline $\begin{array}{l}\text { Ammonia accumulation } \\
\left(\mathrm{mg} \mathrm{L} \mathrm{L}^{-1}\right)\end{array}$ & $2.24 \pm 0.03$ & $2.37 \pm 0.03$ \\
\hline $\begin{array}{l}\mathrm{NaCl} \text { tolerance range } \\
(\mathrm{w} / \mathrm{v}, 0.5-8 \%) 24 \mathrm{~h}\end{array}$ & $1 \times 10^{8} \mathrm{CFU} \mathrm{mL} \mathrm{m}^{-1}$ & $1 \times 10^{8} \mathrm{CFU} \mathrm{mL} \mathrm{m}^{-1}$ \\
\hline $\begin{array}{l}\mathrm{NaCl} \text { tolerance range } \\
(\mathrm{w} / \mathrm{v}, 9-13 \%) 48 \mathrm{~h}\end{array}$ & $1 \times 10^{6} \mathrm{CFU} \mathrm{mL}{ }^{-1}$ & $1 \times 10^{6} \mathrm{CFU} \mathrm{mL} \mathrm{mL}^{-1}$ \\
\hline $\mathrm{pH}$ range at $24 \mathrm{~h}$ & $5-8$ & $5-8$ \\
\hline $\begin{array}{l}\text { Temperature range }\left({ }^{\circ} \mathrm{C}\right) \\
\text { at } 24 \mathrm{~h}\end{array}$ & $28-42$ & $28-42$ \\
\hline Antagonistic activity & $\begin{array}{c}\text { + against Botrytis cinerea } \\
\text { B12, Phytophthora } \\
\text { infestans ph1, } \\
\text { Phytophthora cactorum } \\
\text { ph3, Phytophthora } \\
\text { cryptogea ph4 }\end{array}$ & $\begin{array}{c}\text { + against Botrytis cinerea } \\
\text { B12, Phytophthora } \\
\text { infestans ph1, } \\
\text { Phytophthora cactorum } \\
\text { ph3, Phytophthora } \\
\text { cryptogea ph4 }\end{array}$ \\
\hline
\end{tabular}

${ }^{\dagger} \mathrm{NB}=$ Nutrient Broth. ${ }^{\circledR} \mathrm{NB}+T=$ Nutrient Broth supplemented with L-tryptophan. 


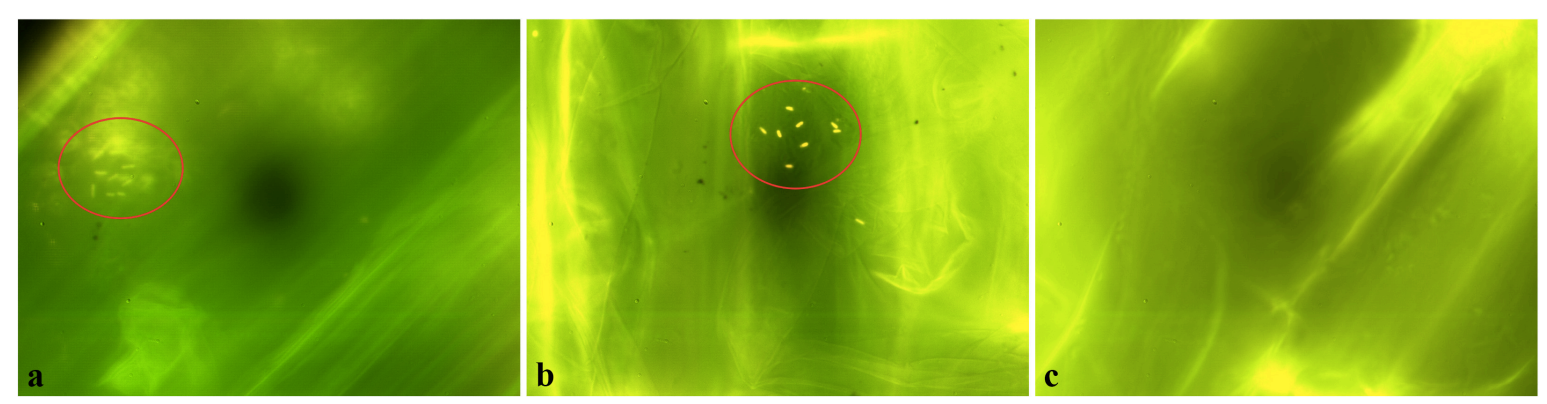

FIGURE 2 | Colonization of tomato's radicles by Kosakonia pseudosacchari TL8 (a), Kosakonia pseudosacchari TL13 (b), and uninoculated control (c) detected by LIVE/DEAD BacLigh bacterial viability kit and observed under fluorescence microscope.

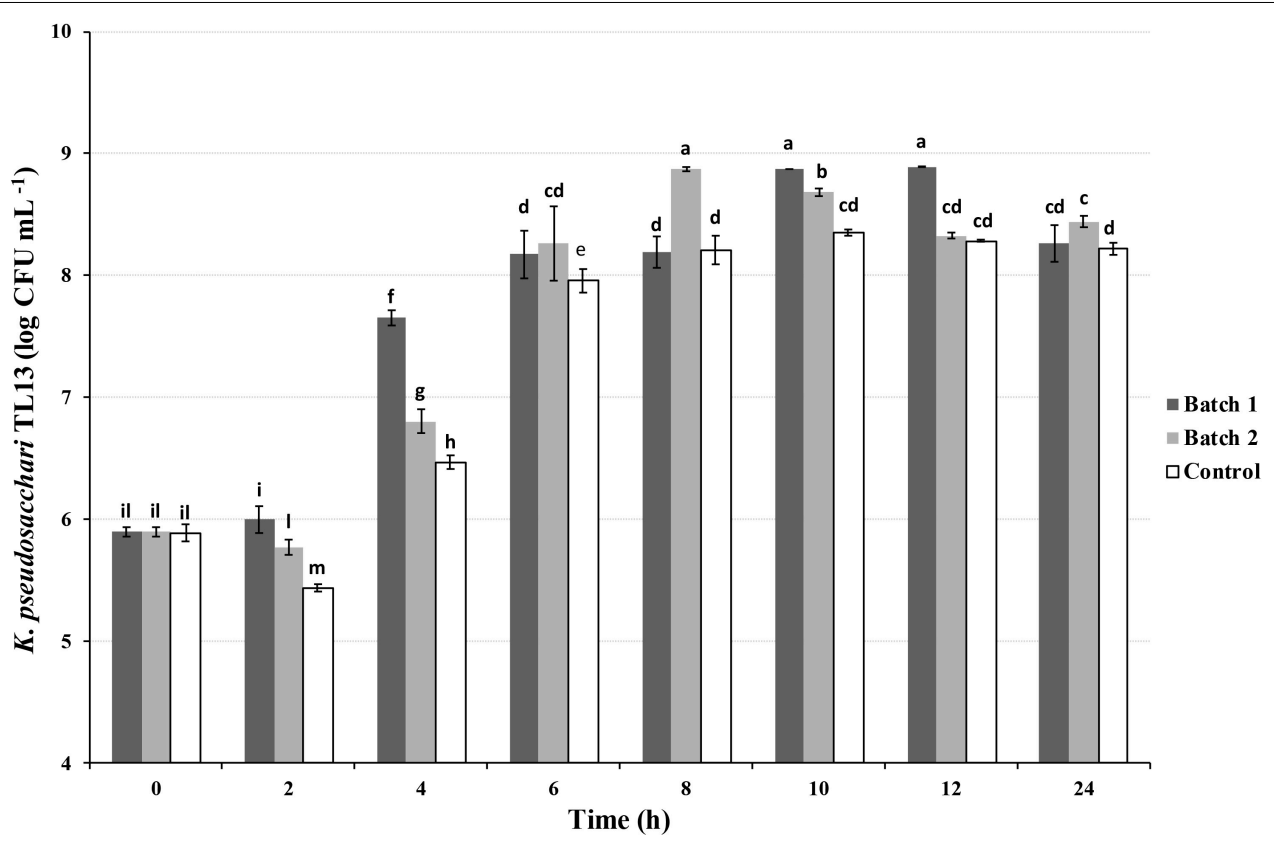

FIGURE 3 | Viable count of Kosakonia pseudosacchari TL13 during its growth in batch experiments using $\mathrm{BH}$ medium $\left(30^{\circ} \mathrm{C}\right.$ and $\left.\mathrm{pH} 7.00\right)$. Batch 1 : shaking at $130 \mathrm{rpm}$; Batch 2: shaking at $130 \mathrm{rpm}$ and air sparging at $0.5 \mathrm{vvm}$; Control: no shaking and no air sparging. The error bars represent the means \pm SD of three replicates. Different letters indicate significant differences $(P<0.05)$.

$\left.8.89 \pm 0.00 \log \mathrm{CFU} \mathrm{mL} \mathrm{m}^{-1}\right)$ in respect to the beginning of the experiment $\left(0 \mathrm{~h} ; 5.90 \pm 0.04 \log \mathrm{CFU} \mathrm{mL} \mathrm{L}^{-1}\right)$, decreasing up to $8.26 \pm 0.15 \log \mathrm{CFU} \mathrm{mL} \mathrm{m}^{-1}$ at $24 \mathrm{~h}$ (Figure 3). However, in both conditions, the $K$. pseudosacchari TL13 load was approximately one order of magnitude greater than that recovered in the control at the same sampling time (ranging from $5.89 \pm 0.07$ to $8.35 \pm 0.03 \log \mathrm{CFU} \mathrm{mL}{ }^{-1}$; Figure 3).

On the basis of these results, growth conditions of batch 2 (shaking at $130 \mathrm{rpm}$ and air sparging at $0.5 \mathrm{vvm}$ ) were chosen to perform the scale-up of the experiment in a $10 \mathrm{~L}$ fermentor. In this condition, although at $8 \mathrm{~h}$ was detected a bacterial concentration ( $8.66 \pm 0.02 \log \mathrm{CFU} \mathrm{mL} \mathrm{m}^{-1}$ ) similar to that recorded in the previous batch experiment, the exponential phase persisted up to $24 \mathrm{~h}$ reaching a bacterial load of $9.33 \pm 0.18$ $\log \mathrm{CFU} \mathrm{mL} \mathrm{m}^{-1}$ (Figure 4). Moreover, to explore the tolerance of the strain $K$. pseudosacchari TL13 to desiccation and to test its shelf-life, the viability of freeze-dried bacterial cells obtained by fermentor experiment was estimated over time. Immediately after freeze-drying, a bacterial concentration of $10.43 \pm 0.10$ $\log$ CFU $\mathrm{g}^{-1}$ was determined. This value remained constant after 3 months of storage $\left(10.40 \pm 0.06 \log \mathrm{CFU} \mathrm{g^{-1 }}\right)$ and decrease of about $1 \log$ after 6 months reaching a concentration of $9.57 \pm 0.14 \log \mathrm{CFU} \mathrm{g}^{-1}$.

\section{Production of Eco-Friendly and Low-Cost Bacterial Inoculants}

Different agro-food industrial by-products were used to obtain an eco-sustainable and cheap carbon source for the growth at industrial level of $K$. pseudosacchari TL13 and its use as inoculant. The strain TL13 resulted able to grow in presence of several carbon sources (whey, protein hydrolysate, exhausted yeasts, or 


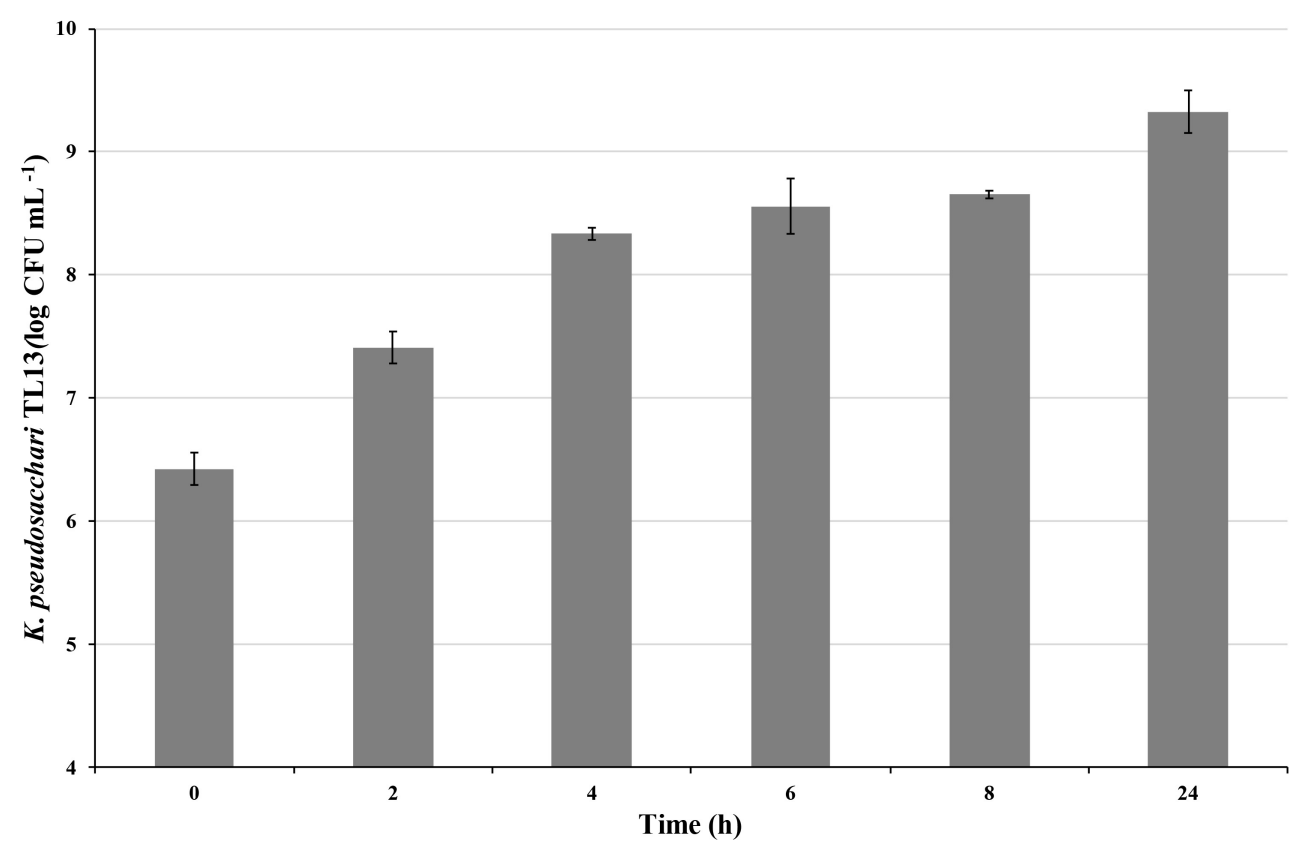

FIGURE 4 | Viable count of Kosakonia pseudosacchari TL13 during its growth in $10 \mathrm{~L}$ fermentor at $30^{\circ} \mathrm{C}, \mathrm{pH} 7.00$, shaking at $130 \mathrm{rpm}$ and air sparging at 0.5 vvm. The error bars represent the means \pm SD of two replicates.

vinasse) at different concentrations (1, 5 and 10\%) reaching a bacterial load of about $8-9 \log \mathrm{CFU} \mathrm{mL} \mathrm{m}^{-1}$ (Table 3). The only exception was the liquid medium containing molasse that determined the lowest bacterial growth at 5\% (7.08 \pm 0.18 $\log \mathrm{CFU} \mathrm{mL}^{-1}$ ) and no growth at 1 and $10 \%$ (Table 3 ). The highest bacterial growth was detected in the medium containing $10 \%$ exhausted yeasts $\left(8.86 \pm 0.21 \log \mathrm{CFU} \mathrm{mL} \mathrm{mL}^{-1}\right)$, that was comparable to the optimal synthetic medium used as control $\left(8.93 \pm 0.01 \log \mathrm{CFU} \mathrm{mL}^{-1}\right)$, followed by the liquid medium containing $5 \%$ vinasse $\left(8.81 \pm 0.07 \log \mathrm{CFU} \mathrm{mL} \mathrm{m}^{-1}\right.$; Table 3). Therefore, SSF on nutrient-supplemented vermiculite of the strain $K$. pseudosacchari TL13 for the production of inoculant was performed using a solution of exhausted yeasts and vinasse. Microbial concentration increased after 15 days of incubation of about three orders of magnitude from $6.81 \pm 0.05$ to $9.34 \pm 0.11 \log \mathrm{CFU} \mathrm{g}^{-1}$. No significant differences $(P>0.05)$ were detected between $K$. pseudosacchari TL13 grown on vermiculite moistened with exhausted yeasts and vinasse and the vermiculite moistened with $\mathrm{BHI}$ used as control $\left(9.20 \pm 0.65 \log \mathrm{CFU} \mathrm{g}^{-1}\right)$.

Solid state fermentation products were used to develop solid and liquid inoculants containing a microbial load of about 6.7-6.9 log CFU $\mathrm{g}^{-1}$ or $\mathrm{mL}^{-1}$, which remained constant up to 28 days.

\section{IN VIVO POT EXPERIMENTS}

Maize plants were positively affected by inoculation with the strain K. pseudosacchari TL13. Indeed, several plant growth parameters significantly increased in the soils treated with solid or liquid inoculants as shown in Table 4. In particular, E-TL13 treatment (raw castor oil/alginate based emulsion containing $K$. pseudosacchari TL13 cells) showed the best results, in which a significant increase $(P<0.05)$ of total plant length $(63.83 \pm 4.51 \mathrm{~cm})$, root length $(23.67 \pm 2.57 \mathrm{~cm})$, and root fresh weight $(1.28 \pm 0.11 \mathrm{~g})$ was recorded in E-TL13 treated plants in respect to the un-inoculated control $(49.17 \pm 3.40 \mathrm{~cm}$, $11.06 \pm 0.90 \mathrm{~cm}$, and $0.80 \pm 0.13 \mathrm{~g}$, respectively; Table 4). Similarly, a significant increase in the root length was also observed in the V-TL13 (dried vermiculite containing K. pseudosacchari TL13 cells) and R-TL13 (K. pseudosacchari TL13 cells diluted in sterile Ringer's solution) treatments reaching values of $18.50 \pm 2.26$ and $23.13 \pm 1.99 \mathrm{~cm}$, respectively (Table 4). Interestingly, V-TL13 treatment induced a significant increase

TABLE 3 | Viable counts of Kosakonia pseudosacchari TL13 (log CFU mL ${ }^{-1}$ ) after $48 \mathrm{~h}$ of growth at $30^{\circ} \mathrm{C}$ in several liquid media containing different agro-industrial by-products as carbon source at three percentage (1, 5, and 10\%).

\begin{tabular}{lccc}
\hline & \multicolumn{2}{c}{ Percentage of by-products in the liquid medium } \\
\cline { 2 - 4 } $\begin{array}{l}\text { Agro-industrial } \\
\text { by-products }\end{array}$ & $\mathbf{1 \%}$ & $\mathbf{5 \%}$ & $\mathbf{1 0 \%}$ \\
\hline Whey & $8.18 \pm 0.02^{e}$ & $7.98 \pm 0.07^{f g}$ & $7.95 \pm 0.03^{f g}$ \\
Protein hydrolysate & $8.05 \pm 0.01^{f}$ & $8.30 \pm 0.03^{d}$ & $8.18 \pm 0.07^{e}$ \\
Exhausted Yeast & $8.30 \pm 0.09^{d}$ & $8.48 \pm 0.08^{c}$ & $8.86 \pm 0.21^{a b}$ \\
Molasse & $0.00 \pm 0.00^{i}$ & $7.08 \pm 0.18^{h}$ & $0.00 \pm 0.00^{\prime}$ \\
Vinasse & $7.94 \pm 0.02^{g}$ & $8.81 \pm 0.07^{b}$ & $7.98 \pm 0.02^{f g}$ \\
BHI (control) & - & $8.93 \pm 0.01^{a}$ & -
\end{tabular}

Values represent the means $\pm S D$ of three replicates. Different letters indicate significant differences $(P<0.05)$. 
TABLE 4 | Effect of different inoculant formulations on total plant length (cm), root length (cm), shoot length (cm), root fresh weight (g), shoot fresh weight (g), root dry weight (\%), shoot dry weight (\%) of maize plants.

\begin{tabular}{|c|c|c|c|c|}
\hline \multirow[b]{2}{*}{ Plant parameters } & \multicolumn{4}{|c|}{ Soil treatment } \\
\hline & V-TL13 & E-TL13 & R-TL13 & C \\
\hline Total plant length (cm) & $51.50 \pm 4.63^{a b}$ & $63.83 \pm 4.5^{a}$ & $58.56 \pm 4.78^{a b}$ & $49.17 \pm 3.40^{b}$ \\
\hline Root length (cm) & $18.50 \pm 2.26^{a b}$ & $23.67 \pm 2.57^{a}$ & $23.13 \pm 1.99^{a}$ & $11.06 \pm 0.90^{b}$ \\
\hline Shoot length $(\mathrm{cm})$ & $33.00 \pm 2.87^{a}$ & $40.17 \pm 2.55^{a}$ & $35.44 \pm 3.68^{a}$ & $38.11 \pm 2.77^{a}$ \\
\hline Root fresh weight (g) & $1.01 \pm 0.15^{a b}$ & $1.28 \pm 0.11^{a}$ & $0.81 \pm 0.15^{b}$ & $0.80 \pm 0.13^{b}$ \\
\hline Shoot fresh weight (g) & $1.19 \pm 0.21^{a}$ & $1.58 \pm 0.14^{a}$ & $1.54 \pm 0.30^{a}$ & $1.30 \pm 0.27^{a}$ \\
\hline Root dry weight (\%) & $15.30 \pm 1.64^{a}$ & $15.03 \pm 1.52^{a}$ & $19.73 \pm 1.08^{a}$ & $17.25 \pm 2.42^{a}$ \\
\hline Shoot dry weight (\%) & $9.62 \pm 0.29^{a}$ & $7.75 \pm 0.64^{a b}$ & $8.53 \pm 0.83^{a b}$ & $6.84 \pm 0.40^{b}$ \\
\hline
\end{tabular}

of shoot dry weight percentage $(9.62 \pm 0.29 \%)$ compared to un-inoculated control (6.84 $\pm 0.40 \%$; Table 4). However, also E-TL13 and R-TL13 treatments showed a similar trend of this plant parameter although no significant differences were detected $(P>0.05$; Table 4).

\section{DISCUSSION}

\section{PGP Traits, Phenotypic Characteristics and Rhizosphere Competence}

In the last decades, the development and the use of microbial inoculants have elicited great interest as an ecofriendly alternative strategy to the application of synthetic fertilizers for plant growth promotion and pest management. This approach improves the sustainability of agricultural systems by reducing environmental and human health risks due to the application of chemical fertilizers and pesticides in crop production (Rahman et al., 2018). In this context, it is necessary to find new microorganisms that can exert multiple plant beneficial activities to develop a low-cost inoculant. The ecological approach developed in this study enabled the isolation of new plant growth-promoting strains K. pseudosacchari TL8 and K. pseudosacchari TL13. This species belongs to the phylum Proteobacteria, and in particular to the $\gamma$-proteobacteria class. This bacterial class, that commonly colonize the rhizosphere of crop plants (Sheridan et al., 2017) or is associated to plant biomass (Montella et al., 2017), is ubiquitous in the soil environment (Ventorino et al., 2019). Indeed, it includes different species that were known to synthesize substances which promote plant growth (i.e., hormones such as IAA, ethylene, and gibberellins), to increase nutrient availability (i.e., $\mathrm{N}, \mathrm{P}, \mathrm{Fe}$ ) and their uptake in soil (Kim et al., 2011) and they act as plant disease-suppressive bacteria (Kobayashi et al., 2002; Haas and Défago, 2005). Therefore, the presence of these populations in the soil highlight its high biological fertility potential because they could improve the growth, fitness and health of agricultural plants playing an important role in the bionetwork function of soils (Ventorino et al., 2018). Although many members belonging to the genus Kosakonia, as $K$. radicincitans, are known to interact and exert beneficial effects on plant growth (Bergottini et al., 2015; Kämpfer et al., 2016; Berger et al., 2017; Brock et al., 2018), PGP properties in K. pseudosacchari species are poorly investigated. Indeed, it was recognized as a novel endophyte species only recently (Kämpfer et al., 2016) and siderophore production was the sole PGP activity previously documented (Arora and Verma, 2017). The main PGP activity by the new PGPR strain K. pseudosacchari TL13 was the production of IAA. About $80 \%$ of rhizospheric microorganisms are able to produce and release auxins as a secondary metabolite, among these IAA is the most common that can contribute to plant-microbe interaction (Olanrewaju et al., 2017). It is an important growth enhancer because it plays a central role in cell division, elongation, fruit development and senescence, and it has a significant effect on plant root system development (Duca et al., 2014). The concentration of IAA produced by the strain TL13 is similar or higher to that recovered in K. radicincitans YD4 strain (about $24 \mu \mathrm{g} \mathrm{mL}^{-1}$ ) by Bergottini et al. (2015). Interestingly, an increase of $50 \%$ of this phytohormone synthesis was observed in the strain grown in the presence of L-tryptophan suggesting a tryptophan-dependent IAA biosynthesis pathway. The synthesis and secretion of IAA could also be linked to the synthesis of ACC synthase in the plant to catalyze the formation of ACC (Glick, 2014). Synthesis of ACC deaminase is also one of the crucial bacterial traits that can facilitate plant growth in the presence of several abiotic or biotic stress (Ali et al., 2014; Glick, 2014). Indeed, K. pseudosacchari strains isolated in this work were able to produce ACC deaminase. As for IAA, this is the first work reporting ACC deaminase activity in K. pseudosacchari species.

Another interesting PGP activity is the production of siderophores. These are iron-chelating agents with low molecular masses (200-2000 Da), which are produced by microorganisms especially when the bioavailability of $\mathrm{Fe}$ is low (Ahmed and Holmström, 2014). Siderophore producing bacteria can improve plant growth by reducing the $\mathrm{Fe}$ availability for the phytopathogens and increasing nutrient availability to the plant (Ahmed and Holmström, 2014). As expected, the two K. pseudosacchari strains TL8 and TL13 were able to produce iron chelating siderophores, a trait commonly present in Kosakonia genus as largely reported by the 
literature (Arora and Verma, 2017; Chimwamurombe et al., 2016; Lambrese et al., 2018). Siderophore production could be involved also in disease suppression. Indeed, PGPR could act also as biocontrol agents against soil-borne plant pathogens by different ways like competing for nutrients or space, limiting available Fe supply through producing siderophores or by the production of lytic enzymes and antibiosis (Bhattacharyya and Jha, 2012). K. pseudosacchari TL8 and TL13 exerted antagonistic activity against Botrytis and Phytophthora species. To the best of our knowledge, this is the first work reporting suppressive effect against plant pathogens in K. pseudosacchari species highlighting that these strains could use also for pest control in agricultural plants.

In addition, $K$. pseudosacchari TL8 and TL13 were also able to solubilize phosphate. Phosphorus is one of the major growth-limiting nutrients required by plants due to its limited availability. There is a great interest in searching phosphate solubilizing bacteria that are able to increase phosphate content and bioavailability in the soil and therefore they are considered promising bio-fertilizers for agriculture enhancement (Kalayu, 2019). Within genus Kosakonia this ability was previously reported only in the strain Kosakonia sp. A37 (Chakdar et al., 2018).

It is known that some PGPB can fix atmospheric nitrogen into ammonium, and consequently increase the availability of this nutrient in the rhizosphere. The use of these microorganisms in agriculture could decrease the use of chemical N-based fertilizers and therefore their negative impact on the environment as soil quality depletion, pollution and human health (Noar and Bruno-Bárcena, 2018). According to previous works in which several Kosakonia species were described as $\mathrm{N}_{2}$-fixing bacteria (Chen et al., 2014; Chin et al., 2017; Sun et al., 2018), the new strains $K$. pseudosacchari TL8 and TL13 were able to produce ammonia and potentially able to fix atmospheric nitrogen due to the presence of the nif $\mathrm{H}$ gene encoding nitrogenase reductase enzyme.

Kosakonia pseudosacchari TL8 and K. pseudosacchari TL13 showed also interesting abiotic stress tolerance because they were able to grow in a wide range of temperature, $\mathrm{pH}$ and salt. These phenotypic properties could help the tolerance of crops cultivated in stress conditions. In particular, salinity is one of the most common abiotic stress in modern agriculture because the irrigation of summer crops with saline water, especially in the coastal regions, lead to an increase of soil salinization in many areas of the world causing major problems for the productivity of agricultural crops and reducing the soil microbial activity (Kumar and Verma, 2018).

As observed in vitro assay under fluorescence microscope after treatment with BacLight bacterial viability kit, $K$. pseudosacchari TL8 and TL13 were able to colonize tomato radicles. This result was in according to Kämpfer et al. (2016) which describe $K$. pseudosacchari species as an endophyte of maize plants. Moreover, this ability was also described for other Kosakonia species as K. radicincitans, able to colonize the root surface of winter wheat (Witzel et al., 2017), or of cucumbers (Sun et al., 2018).

\section{Production of a Low-Cost and Eco-Sustainable Bacterial Inoculants and Their Effectiveness in Inoculated Plants}

Based on PGP traits, the strain K. pseudosacchari TL13 was selected for the production of a new low-cost and eco-sustainable bacterial inoculant. In order to develop new bacterial inoculants and to ensure the application of a suitable number of viable and active microbial cells, high biomass production, formulation and shelf life are crucial steps (Bashan et al., 2014). Preliminary investigations in synthetic medium allowed us to assess the growth curve and the best growth condition and parameters to increase bacterial biomass and to obtain a suitable microbial concentration of the strain K. pseudosacchari TL13. Besides, microbial cells of TL13 were also subjected to freeze-drying, a common method for preserving bacteria, in order to evaluate their shelf life over time. Although freeze-dried K. pseudosacchari TL13 remained viable up to 6 months, this approach could not be suitable at industrial level for its higher production costs than others as foam drying (Morgan et al., 2006). Indeed, production costs of a bio-formulate, which include raw material, equipment and staff, must be competitive in relation to that for the production of chemical fertilizers (Lobo et al., 2019). In general, the use of a low-cost culture medium for the growth and production of microbial biomass is an important issue (Liu et al., 2014; Xu et al., 2015). In this work, to reduce the costs and to develop an eco-sustainable inoculant, the use of several agro-industrial by-products as carbon source was evaluated for the production of K. pseudosacchari TL13 by SSF on vermiculite. Indeed, valorization of organic waste biomass and by-products derived from agriculture and food processing factories by a sustainable and harmless disposal have generated interest in microbial biotechnologies (Pagliano et al., 2019). This new approach to by-products management is eco-friendly, easy to be conducted and economically advantageous. Interestingly, K. pseudosacchari TL13 was able to use different organic by-products as carbon source although the highest bacterial growth was observed in liquid media containing exhausted yeasts or vinasse. This approach allowed to obtain a suitable bacterial concentration $\left(10^{6} \mathrm{CFU} \mathrm{mL} \mathrm{m}^{-1}\right.$ or $\left.\mathrm{g}^{-1}\right)$ in the two final, solid (vermiculite-based) or liquid (raw castor oil/alginatebased emulsion), bio-formulations. The development of two kinds of formulations was important to evaluate their different advantages. Indeed, liquid emulsion formulation allowed to protect the bio-inoculant from desiccation as well as from osmotic and oxidative stress (John et al., 2010); whereas, solid vermiculite-based inoculants were very stable, require no special storage and has good seed-sticking properties (Graham-Weiss et al., 1987). Although, both K. pseudosacchari TL13 formulations exerted positive effects on maize plants cultivated in unsterilized soil, the liquid raw castor oil/alginate-based emulsion showed the best results increasing several plant parameters. Liquid formulations are often preferred by users because the product is ready to use. However, the stable and low-cost solid vermiculitebased formulation could be used in agricultural crops for increasing dry matter. These results are in accord with previous 
works in which inoculum of Kosakonia sp. strains were able to exert positive effects in various crops as radish (Berger et al., 2015), yerba mate (Bergottini et al., 2015), tomato (Berger et al., 2017), and maize (Berger et al., 2018).

\section{CONCLUSION}

The K. pseudosacchari strains isolated in this study showed multiple PGP traits as well as antimicrobial activity against several soilborne plant pathogens. In particular, the new selected strain K. pseudosacchari TL13 was able to colonize plant roots and improve plant growth. To our knowledge, this is the first work reporting effective multiple PGP abilities and antimicrobial activity in K. pseudosacchari species. Moreover, the ability of K. pseudosacchari TL13 to efficiently use agro-industrial organic by-products as carbon source for its metabolism makes this strain a promising candidate for the development of new biofertilizers for sustainable agriculture.

\section{DATA AVAILABILITY STATEMENT}

The datasets presented in this study can be found in online repositories. The names of the repository/repositories and accession number(s) can be found at: https://www.ncbi.nlm.nih. gov/genbank/, MN607213 and MN607214.

\section{REFERENCES}

Ahmed, E., and Holmström, S. J. M. (2014). Siderophores in environmental research: roles and applications. Microb. Biotechnol. 7, 196-208. doi: 10.1111/ 1751-7915.12117

Alfonzo, A., Lo Piccolo, S., Conigliaro, G., Ventorino, V., Burruano, S., and Moschetti, G. (2012). Antifungal peptides produced by Bacillus amyloliquefaciens AG1 active against grapevine fungal pathogens. Ann. Microbiol. 62, 1593-1599. doi: 10.1007/s13213-011-0415-2

Ali, S., Charles, T. C., and Glick, B. R. (2014). Amelioration of high salinity stress damage by plant growth-promoting bacterial endophytes that contain ACC deaminase. Plant. Physiol. Bioch 80, 160-167. doi: 10.1016/j.plaphy.2014. 04.003

Alori, E. T., and Babalola, O. O. (2018). Microbial inoculants for improving crop quality and human health in Africa. Front. Microbiol. 9:2213. doi: 10.3389/ fmicb.2018.02213

Amarasinghe, R. M. N. T., Wang, J.-H., Xie, W. X., Peng, L. C., Li, S.-F., and $\mathrm{Li}, \mathrm{H}$. (2018). Seed-sterilization of rhododendron wardii for micropropagation, Sri Lanka. J. Food Agric. 4, 9. doi: 10.4038/sljfa.v4i1.51

Aquilanti, L., Favilli, F., and Clementi, F. (2004). Comparison of different strategies for isolation and preliminary identification of azotobacter from soil samples. Soil Biol. Biochem. 36, 1475-1483. doi: 10.1016/j.soilbio.2004.04.024

Arora, N. K., and Verma, M. (2017). Modified microplate method for rapid and efficient estimation of siderophore produced by bacteria. 3 Biotech. 7:381. doi: 10.1007/s13205-017-1008-y

Backer, R., Rokem, J. S., Ilangumaran, G., Lamont, J., Praslickova, D., Ricci, E., et al. (2018). Plant growth-promoting rhizobacteria: context, mechanisms of action, and roadmap to commercialization of biostimulants for sustainable agriculture. Front. Plant Sci. 9:1473. doi: 10.3389/fpls.2018.01473

Banik, A., Mukhopadhaya, S. K., Sahana, A., Das, D., and Dangar, T. K. (2016). Fluorescence resonance energy transfer (FRET)-based technique for tracking of endophytic bacteria in rice roots. Biol. Fertil. Soils 52, 277-282. doi: 10.1007/ s00374-015-1064-6

\section{AUTHOR CONTRIBUTIONS}

IR performed the experiments, analyzed the data, and drafted the manuscript. VV significantly contributed in results interpretation and drafted the manuscript. PA coordinated the development of bio-formulates and in vivo experiments. FC contributed to plant-growth promoting assays and evaluation of microbial growth in liquid media containing agro-industrial by-products. AT provided the soilborne plant pathogens. OP conceived the study and participated in its design and coordination. All authors approved and reviewed the manuscript.

\section{FUNDING}

This work was supported by FSE-FESR PON R\&I 2014-2020, Ph.D. program on "Sustainable agricultural and forestry systems and food security" - XXXIII cycle and by Agriges S.r.l. within the research project "BENEVEGEFIT", MISE-Agrifood PON I\&C 2014-2020.

\section{ACKNOWLEDGMENTS}

The authors thank Alessandro Robertiello for technical support in batch and fermentor experiments.

Bashan, Y., de-Bashan, L. E., Prabhu, S. R., and Hernandez, J.-P. (2014). Advances in plant growth-promoting bacterial inoculant technology: formulations and practical perspectives (1998-2013). Plant Soil 378, 1-33. doi: 10.1007/s11104013-1956-x

Berger, B., Baldermann, S., and Ruppel, S. (2017). The plant growth-promoting bacterium Kosakonia radicincitans improves fruit yield and quality of Solanum lycopersicum. J. Sci. Food Agric. 97, 4865-4871. doi: 10.1002/jsfa.8357

Berger, B., Patz, S., Ruppel, S., Dietel, K., Faetke, S., Junge, H., et al. (2018). Successful formulation and application of plant growth-promoting Kosakonia radicincitans in maize cultivation. Biomed. Res. Int. 2018, 1-8. doi: 10.1155/ 2018/6439481

Berger, B., Wiesner, M., Brock, A. K., Schreiner, M., and Ruppel, S. (2015). K. radicincitans, a beneficial bacteria that promotes radish growth under field conditions. Agron. Sustain. Dev. 35, 1521-1528. doi: 10.1007/s13593-0150324-Z

Bergottini, V. M., Otegui, M. B., Sosa, D. A., Zapata, P. D., Mulot, M., Rebord, M., et al. (2015). Bio-inoculation of yerba mate seedlings (Ilex paraguariensis St. Hill.) with native plant growth-promoting rhizobacteria: a sustainable alternative to improve crop yield. Biol. Fertil. Soils 51, 749-755. doi: 10.1007/ s00374-015-1012-5

Bhattacharyya, P. N., and Jha, D. K. (2012). Plant growth-promoting rhizobacteria (PGPR): emergence in agriculture. World J. Microbiol. Biotechnol. 28, 13271350. doi: 10.1007/s11274-011-0979-9

Brock, A. K., Berger, B., Schreiner, M., Ruppel, S., and Mewis, I. (2018). Plant growth-promoting bacteria Kosakonia radicincitans mediate anti-herbivore defense in Arabidopsis thaliana. Planta 248, 1383-1392. doi: 10.1007/s00425018-2964-0

Cappuccino, J. G., and Sherman, N. (1987). Microbiology: A Laboratory Manual, 3rd Edn, New York, NY: Benjamin-Cummings Publishing Company.

Castanheira, N. L., Dourado, A. C., Pais, I., Semedo, J., Scotti-Campos, P., Borges, N., et al. (2017). Colonization and beneficial effects on annual ryegrass by mixed inoculation with plant growth promoting bacteria. Microbiol. Res. 198, 47-55. doi: 10.1016/j.micres.2017.01.009 
Chakdar, H., Dastager, S. G., Khire, J. M., Rane, D., and Dharne, M. S. (2018). Characterization of mineral phosphate solubilizing and plant growth promoting bacteria from termite soil of arid region. 3 Biotech. 8:463. doi: 10 . 1007/s13205-018-1488-4

Chen, M., Zhu, B., Lin, L., Yang, L., Li, Y., and An, Q. (2014). Complete genome sequence of Kosakonia sacchari type strain SP1T. Stand. Genomic Sci. 9, 13111318. doi: 10.4056/sigs.5779977

Chimwamurombe, P. M., Grönemeyer, J. L., and Reinhold-Hurek, B. (2016). Isolation and characterization of culturable seed-associated bacterial endophytes from gnotobiotically grown Marama bean seedlings. FEMS Microbiol. Ecol. 92:fiw083. doi: 10.1093/femsec/fiw083

Chin, C. F. S., Furuya, Y., Zainudin, M. H. M., Ramli, N., Hassan, M. A., Tashiro, Y., et al. (2017). Novel multifunctional plant growth-promoting bacteria in co-compost of palm oil industry waste. J. Biosci. Bioeng. 124, 506-513. doi: 10.1016/j.jbiosc.2017.05.016

Dal Cortivo, C., Barion, G., Visioli, G., Mattarozzi, M., Mosca, G., and Vamerali, T. (2017). Increased root growth and nitrogen accumulation in common wheat following PGPR inoculation: assessment of plant-microbe interactions by ESEM. Agric. Ecosyst. Environ. 247, 396-408. doi: 10.1016/j.agee.2017. 07.006

DM 27/01/2014 (2014). Metodi Di Analisi Per Il Controllo Ufficiale Dei Fertilizzanti. Supplemento n. 12. Gazzetta Ufficiale 42 Del 20/02/2014.

Dorais, M., and Alsanius, B. W. (2016). Recent advances in organic horticulture technology and management. Sci. Hortic. 208, 1-2. doi: 10.1016/j.scienta.2016. 07.006

Duca, D., Lorv, J., Patten, C. L., Rose, D., and Glick, B. R. (2014). Indole-3-acetic acid in plant-microbe interactions. Antonie Van Leeuwenhoek 106, 85-125. doi: 10.1007/s10482-013-0095-y

Fiorentino, N., Ventorino, V., Bertora, C., Pepe, O., Giancarlo, M., Grignani, C., et al. (2016). Changes in soil mineral $\mathrm{N}$ content and abundances of bacterial communities involved in $\mathrm{N}$ reactions under laboratory conditions as predictors of soil N availability to maize under field conditions. Biol. Fertil. Soils 52, 523-537. doi: 10.1007/s00374-016-1095-7

Fiorentino, N., Ventorino, V., Woo, S. L., Pepe, O., De Rosa, A., Gioia, L., et al. (2018). Trichoderma-based biostimulants modulate rhizosphere microbial populations and improve $\mathrm{N}$ uptake efficiency, yield, and nutritional quality of leafy vegetables. Front. Plant Sci. 9:743. doi: 10.3389/fpls.2018.00743

Fravel, D. R., Marois, J. J., Lumsden, R. D., and Connick, W. J. Jr. (1985). Encapsulation of potential biocontrol agents in an alginate-clay matrix. Phytopathology 75, 774-777. doi: 10.1094/phyto-75-774

Glick, B. R. (2014). Bacteria with ACC deaminase can promote plant growth and help to feed the world. Microbiol. Res. 169, 30-39. doi: 10.1016/j.micres.2013. 09.009

Graham-Weiss, L., Bennett, M. L., and Paau, A. S. (1987). Production of bacterial inoculants by direct fermentation on nutrient-supplemented vermiculite. Appl. Environ. Microbiol. 53, 2138-2141. doi: 10.1128/aem.53.9.2138-2141.1987

Haas, D., and Défago, G. (2005). Biological control of soil-borne pathogens by fluorescent pseudomonads. Nat. Rev. Microbiol. 3, 307-319. doi: 10.1038/ nrmicro1129

Hammami, I., Hsouna, A. B., Hamdi, N., Gdoura, R., and Triki, M. A. (2013). Isolation and characterization of rhizosphere bacteria for the biocontrol of the damping-off disease of tomatoes in Tunisia. C. R. Biol. 336, 557-564. doi: 10.1016/j.crvi.2013.10.006

Hossain, M. I., Sadekuzzaman, M., and Ha, S. D. (2017). Probiotics as potential alternative biocontrol agents in the agriculture and food industries: a review. Food Res. Int. 100, 63-73. doi: 10.1016/j.foodres.2017.07.077

Jaemsaeng, R., Jantasuriyarat, C., and Thamchaipenet, A. (2018). Molecular interaction of 1-aminocyclopropane-1-carboxylate deaminase (ACCD)producing endophytic Streptomyces sp. GMKU 336 towards salt-stress resistance of Oryza sativa L. cv. KDML105. Sci. Rep. 8:1950. doi: 10.1038/s41598-018-19799-9

John, R. P., Tyagi, R. D., Brar, S. K., and Prévost, D. (2010). Development of emulsion from rhizobial fermented starch industry wastewater for application as medicago sativa seed coat. Eng. Life Sci. 10, 248-256. doi: 10.1002/elsc. 201000002

Kalayu, G. (2019). Phosphate solubilizing microorganisms: promising approach as biofertilizers. Int. J. Agron. 2019:4917256. doi: 10.1155/2019/491 7256
Kämpfer, P., McInroy, J. A., Doijad, S., Chakraborty, T., and Glaeser, S. P. (2016) Kosakonia pseudosacchari sp. nov., an endophyte of Zea mays. Syst. Appl. Microbiol. 39, 1-7. doi: 10.1016/j.syapm.2015.09.004

Kandel, S. L., Joubert, P. M., and Doty, S. L. (2017). Bacterial endophyte colonization and distribution within plants. Microorganisms 5:E77. doi: 10 . 3390/microorganisms5040077

Khalid, M., Hassani, D., Bilal, M., Asad, F., and Huang, D. (2017). Influence of bio-fertilizer containing beneficial fungi and rhizospheric bacteria on health promoting compounds and antioxidant activity of Spinacia oleracea L. Bot. Stud. 58:35. doi: 10.1186/s40529-017-0189-3

Kim, W. I., Cho, W. K., Kim, S. N., Chu, H., Ryu, K. Y., Yun, J. C., et al. (2011). Genetic diversity of cultivable plant growth-promoting rhizobacteria in Korea. J. Microbiol. Biotechnol. 21, 777-790. doi: 10.4014/jmb.1101.01031

Kobayashi, D. Y., Reedy, R. M., Bick, J. A., and Oudemans, P. V. (2002). Characterization of a chitinase gene from Stenotrophomonas maltophilia strain 34 S1 and its involvement in biological control. Appl. Environ. Microbiol. 68, 1047-1054. doi: 10.1128/aem.68.3.1047-1054.2002

Kumar, A., and Verma, J. P. (2018). Does plant-Microbe interaction confer stress tolerance in plants: a review? Microbiol. Res. 207, 41-52. doi: 10.1016/j.micres. 2017.11.004

Kumar, S., Stecher, G., Li, M., Knyaz, C., and Tamura, K. (2018). MEGA X: molecular evolutionary genetics analysis across computing platforms. Mol. Biol. Evol. 35, 1547-1549. doi: 10.1093/molbev/msy096

Lambrese, Y., Guiñez, M., Calvente, V., Sansone, G., Cerutti, S., Raba, J., et al. (2018). Production of siderophores by the bacterium Kosakonia radicincitans and its application to control of phytopathogenic fungi. Bioresour. Technol. Rep. 3, 82-87. doi: 10.1016/j.biteb.2018.06.003

Liu, J., Yang, J., Liang, X., Zhao, Y., Cade-Menun, B. J., and Hu, Y. (2014). Molecular speciation of phosphorus present in readily dispersible colloids from agricultural soils. Soil Sci. Soc. Am. J. 78, 47-53. doi: 10.2136/sssaj2013. 05.0159

Lobo, C. B., Juárez Tomás, M. S., Viruel, E., Ferrero, M. A., and Lucca, M. E. (2019) Development of low-cost formulations of plant growth-promoting bacteria to be used as inoculants in beneficial agricultural technologies. Microbiol. Res. 219, 12-25. doi: 10.1016/j.micres.2018.10.012

Montella, S., Ventorino, V., Lombard, V., Henrissat, B., Pepe, O., and Faraco, V. (2017). Discovery of genes coding for carbohydrate-active enzyme by metagenomic analysis of lignocellulosic biomasses. Sci. Rep. 7:42623. doi: 10. 1038/srep42623

Morgan, C. A., Herman, N., White, P. A., and Vesey, G. (2006). Preservation of micro-organisms by drying. A review. J. Microbiol. Methods 66, 183-193. doi: 10.1016/j.mimet.2006.02.017

Murphy, J., and Riley, J. P. (1962). A modified single solution method for the determination of phosphate in natural waters. Anal. Chim. Acta 27, 31-36. doi: 10.1016/s0003-2670(00)88444-5

Noar, J. D., and Bruno-Bárcena, J. M. (2018). Azotobacter vinelandii: the source of 100 years of discoveries and many more to come. Microbiology 164, 421-436. doi: $10.1099 / \mathrm{mic} .0 .000643$

Olanrewaju, O. S., Glick, B. R., and Babalola, O. O. (2017). Mechanisms of action of plant growth promoting bacteria. World J. Microbiol. Biotechnol. 33:197. doi: 10.1007/s11274-017-2364-9

Pagliano, G., Ventorino, V., Panico, A., Romano, I., Pirozzi, F., and Pepe, O. (2019). Anaerobic process for bioenergy recovery from dairy waste: meta-analysis and enumeration of microbial community related to intermediates production. Front. Microbiol. 9:3229. doi: 10.3389/fmicb.2018.03229

Passari, A. K., Mishra, V. K., Singh, G., Singh, P., Kumar, B., Gupta, V. K., et al. (2017). Insights into the functionality of endophytic actinobacteria with a focus on their biosynthetic potential and secondary metabolites production. Sci. Rep. 7:11809. doi: 10.1038/s41598-017-12235-4

Payne, S. M. (1993). Iron acquisition in microbial pathogenesis. Trends Microbiol. 1, 66-69. doi: 10.1016/0966-842x(93)90036-q

Penrose, D. M., and Glick, B. R. (2003). Methods for isolating and characterizing ACC deaminase-containing plant growth-promoting rhizobacteria. Physiol. Plant. 118, 10-15. doi: 10.1034/j.1399-3054.2003.00086.x

Pepe, O., Ventorino, V., and Blaiotta, G. (2013). Dynamic of functional microbial groups during mesophilic composting of agro-industrial wastes and free-living (N2)-fixing bacteria application. Waste Manag. 33, 1616-1625. doi: 10.1016/j. wasman.2013.03.025 
Rahman, M., Sabir, A. A., Mukta, J. A., Khan, M. M. A., Mohi-Ud-Din, M., Miah, M. G., et al. (2018). Plant probiotic bacteria Bacillus and paraburkholderia improve growth, yield and content of antioxidants in strawberry fruit. Sci. Rep. 8:2504. doi: 10.1038/s41598-018-20235-1

Romano, I., Ventorino, V., and Pepe, O. (2020). Effectiveness of plant beneficial microbes: overview of the methodological approaches for the assessment of root colonization and persistence. Front. Plant Sci. 11:6. doi: 10.3389/fpls.2020. 00006

Rösch, C., Mergel, A., and Bothe, H. (2002). Biodiversity of denitrifying and dinitrogen-fixing bacteria in an acid forest soil. Appl. Environ. Microbiol. 68, 3818-3829. doi: 10.1128/aem.68.8.3818-3829.2002

Sharma, S. D., Kumar, P., Bhardwaj, S. K., and Yadav, S. K. (2011). Screening and selecting novel AM fungi and Azotobacter strain for inoculating apple under soilsolarization and chemical disinfestation with mulch practices for sustainable nursery management. Sci. Hortic. 130, 164-174. doi: 10.1016/j.scienta.2011. 06.032

Sheridan, C., Depuydt, P., De Ro, M., Petit, C., Van Gysegem, E., Delaere, P., et al. (2017). Microbial community dynamics and response to plant growthpromoting microorganisms in the rhizosphere of four common food crops cultivated in hydroponics. Microb. Ecol. 73, 378-393. doi: 10.1007/s00248-0160855-0

Silva-Stenico, M. E., Pacheco, F. T. H., Rodrigues, J. L. M., Carrilho, E., and Tsai, S. M. (2005). Growth and siderophore production of Xylella fastidiosa under iron-limited conditions. Microbiol. Res. 160, 429-436. doi: 10.1016/j.micres. 2005.03.007

Singh, S. R., Zargar, M. Y., Najar, G. R., Peer, F. A., and Ishaq, M. (2013). Microbial dynamics, root colonization, and nutrient availability as influenced by inoculation of liquid bioinoculants in cultivars of apple seedlings. Commun. Soil Sci. Plant Anal. 44, 1511-1523. doi: 10.1080/00103624.2012. 760571

Stecher, G., Tamura, K., and Kumar, S. (2020). Molecular evolutionary genetics analysis (MEGA) for macOS. Mol. Biol. Evol. 37, 1237-1239. doi: 10.1093/ molbev/msz312

Sun, S., Chen, Y., Cheng, J., Li, Q., Zhang, Z., and Lan, Z. (2018). Isolation, characterization, genomic sequencing, and GFP-marked insertional mutagenesis of a high-performance nitrogen-fixing bacterium, Kosakonia radicincitans GXGL-4A and visualization of bacterial colonization on cucumber roots. Folia Microbiol. 63, 789-802. doi: 10.1007/s12223-018-0608-1

Thompson, J. D., Higgins, D. G., and Gibson, T. J. (1994). CLUSTAL W: improving the sensitivity of progressive multiple sequence alignment through sequence weighting, position-specific gap penalties and weight matrix choice. Nucleic Acids Res. 22, 4673-4680. doi: 10.1093/nar/22.22.4673

Timmusk, S., Behers, L., Muthoni, J., Muraya, A., and Aronsson, A. C. (2017). Perspectives and challenges of microbial application for crop improvement. Front. Plant Sci. 8:49. doi: 10.3389/fpls.2017.00049

Van Oosten, M. J., Pepe, O., De Pascale, S., Silletti, S., and Maggio, A. (2017). The role of biostimulants and bioeffectors as alleviators of abiotic stress in crop plants. Chem. Biol. Technol. Agric. 4:5. doi: 10.1186/s40538-017-0089-5

Ventorino, V., Caputo, R., De Pascale, S., Fagnano, M., Pepe, O., and Moschetti, G. (2012a). Response to salinity stress of Rhizobium leguminosarum bv. viciae strains in the presence of different legume host plants. Ann. Microbiol. 62, 811-823. doi: 10.1007/s13213-011-0322-6

Ventorino, V., De Marco, A., Pepe, O., De Santo, A. V., and Moschetti, G. (2012b). "Impact of innovative agricultural practices of carbon sequestration on soil microbial community," in Carbon Sequestration in Agricultural Soils.
A Ultidisciplinary Approach to Innovative Methods, ed. A. Piccolo (Berlin: Springer), 145-177. doi: 10.1007/978-3-642-23385-2_6

Ventorino, V., Ionata, E., Birolo, L., Montella, S., Marcolongo, L., de Chiaro, A., et al. (2016). Lignocellulose-adapted endo-cellulase producing Streptomyces strains for bioconversion of cellulose-based materials. Front. Microbiol. 7:2061. doi: $10.3389 /$ fmicb.2016.02061

Ventorino, V., Pascale, A., Adamo, P., Rocco, C., Fiorentino, N., Mori, M., et al. (2018). Comparative assessment of autochthonous bacterial and fungal communities and microbial biomarkers of polluted agricultural soils of the Terra dei Fuochi. Sci. Rep. 8:14281. doi: 10.1038/s41598-018-32688-5

Ventorino, V., Pascale, A., Fagnano, M., Adamo, P., Faraco, V., Rocco, C., et al. (2019). Soil tillage and compost amendment promote bioremediation and biofertility of polluted area. J. Clean. Prod. 239:118087. doi: 10.1016/j.jclepro. 2019.118087

Ventorino, V., Robertiello, A., Cimini, D., Argenzio, O., Schiraldi, C., Montella, S., et al. (2017). Bio-based succinate production from Arundo donax hydrolysate with the new natural succinic acid-producing strain Basfia succiniciproducens BPP7. Bioenergy Res. 10, 488-498. doi: 10.1007/s12155-017-9814-y

Ventorino, V., Sannino, F., Piccolo, A., Cafaro, V., Carotenuto, R., and Pepe, O. (2014). Methylobacterium populi VP2: plant growth-promoting bacterium isolated from a highly polluted environment for polycyclic aromatic hydrocarbon (PAH) biodegradation. Sci. World J. 2014, 931793. doi: 10.1155/ 2014/931793

Viscardi, S., Ventorino, V., Duran, P., Maggio, A., De Pascale, S., Mora, M. L., et al. (2016). Assessment of plant growth promoting activities and abiotic stress tolerance of Azotobacter chroococcum strains for a potential use in sustainable agriculture. J. Soil Sci. Plant Nutr. 16, 848-863. doi: 10.4067/s071895162016005000060

Wang, C., Wu, W., Wei, L., Feng, L., Kang, M., Xie, Y., et al. (2019). Kosakonia quasisacchari sp. nov. recovered from human wound secretion in China. Int. J. Syst. Evol. Microbiol. 69, 3155-3160. doi: 10.1099/ijsem.0.003606

Witzel, K., Strehmel, N., Baldermann, S., Neugart, S., Becker, Y., Becker, M., et al. (2017). Arabidopsis thaliana root and root exudate metabolism is altered by the growth-promoting bacterium Kosakonia radicincitans DSM 16656T. Plant Soil 419, 557-573. doi: 10.1007/s11104-017-3371-1

Woo, S. L., and Pepe, O. (2018). Microbial consortia: promising probiotics as plant biostimulants for sustainable agriculture. Front. Plant Sci. 9:1801. doi: 10.3389/fpls.2018.01801

Xu, S., Bai, Z., Jin, B., Xiao, R., and Zhuang, G. (2015). Bioconversion of wastewater from sweet potato starch production to Paenibacillus polymyxa biofertilizer for tea plants. Sci. Rep. 4:4131. doi: 10.1038/srep04131

Conflict of Interest: PA was employed by Agriges S.r.l.

The authors declare that this study received funding from Agriges S.r.l. The funder had the following involvement in the study: coordination of the development of bio-formulates and in vivo experiments.

Copyright (๑) 2020 Romano, Ventorino, Ambrosino, Testa, Chouyia and Pepe. This is an open-access article distributed under the terms of the Creative Commons Attribution License (CC BY). The use, distribution or reproduction in other forums is permitted, provided the original author(s) and the copyright owner(s) are credited and that the original publication in this journal is cited, in accordance with accepted academic practice. No use, distribution or reproduction is permitted which does not comply with these terms. 